\title{
Growth in $\mathrm{NO}_{\mathrm{x}}$ emissions from power plants in China: bottom-up estimates and satellite observations
}

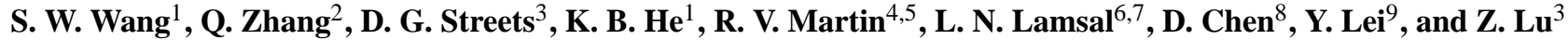 \\ ${ }^{1}$ State Key Joint Laboratory of Environment Simulation and Pollution Control, School of Environment, Tsinghua University, \\ Beijing, China \\ ${ }^{2}$ Ministry of Education Key Laboratory for Earth System Modeling, Center for Earth System Science, Tsinghua University, \\ Beijing, China \\ ${ }^{3}$ Decision and Information Sciences Division, Argonne National Laboratory, Argonne, IL, USA \\ ${ }^{4}$ Department of Physics and Atmospheric Science, Dalhousie University, Halifax, NS, Canada \\ ${ }^{5}$ Harvard-Smithsonian Center for Astrophysics, Cambridge, MA, USA \\ ${ }^{6}$ Goddard Earth Sciences Technology and Research, Universities Space Research Association, Columbia, MD, USA \\ ${ }^{7}$ NASA Goddard Space Flight Center, Greenbelt, MD, USA \\ ${ }^{8}$ Department of Atmospheric and Oceanic Sciences, University of California at Los Angeles, Los Angeles, CA, USA \\ ${ }^{9}$ Key Laboratory of Environmental Planning and Policy Simulation, Chinese Academy for Environmental Planning, \\ Beijing, China
}

Correspondence to: Q. Zhang (qiangzhang@tsinghua.edu.cn)

Received: 18 November 2011 - Published in Atmos. Chem. Phys. Discuss.: 2 January 2012

Revised: 13 April 2012 - Accepted: 22 April 2012 - Published: 21 May 2012

\begin{abstract}
Using OMI (Ozone Monitoring Instrument) tropospheric $\mathrm{NO}_{2}$ columns and a nested-grid 3-D global chemical transport model (GEOS-Chem), we investigated the growth in $\mathrm{NO}_{\mathrm{x}}$ emissions from coal-fired power plants and their contributions to the growth in $\mathrm{NO}_{2}$ columns in 2005-2007 in China. We first developed a unit-based power plant $\mathrm{NO}_{\mathrm{x}}$ emission inventory for 2005-2007 to support this investigation. The total capacities of coal-fired power generation have increased by $48.8 \%$ in $2005-2007$, with $92.2 \%$ of the total capacity additions coming from generator units with size $\geq 300 \mathrm{MW}$. The annual $\mathrm{NO}_{\mathrm{x}}$ emissions from coal-fired power plants were estimated to be $8.11 \mathrm{Tg} \mathrm{NO} \mathrm{NO}_{2}$ for 2005 and $9.58 \mathrm{Tg} \mathrm{NO} \mathrm{NO}_{2}$ for 2007 , respectively. The modeled summer average tropospheric $\mathrm{NO}_{2}$ columns were highly correlated $\left(R^{2}=0.79-0.82\right)$ with OMI measurements over grids dominated by power plant emissions, with only 7-14\% low bias, lending support to the high accuracy of the unitbased power plant $\mathrm{NO}_{\mathrm{x}}$ emission inventory. The ratios of OMI-derived annual and summer average tropospheric $\mathrm{NO}_{2}$ columns between 2007 and 2005 indicated that most of the grids with significant $\mathrm{NO}_{2}$ increases were related to power plant construction activities. OMI had the capability to trace
\end{abstract}

the changes of $\mathrm{NO}_{\mathrm{x}}$ emissions from individual large power plants in cases where there is less interference from other $\mathrm{NO}_{\mathrm{x}}$ sources. Scenario runs from GEOS-Chem model suggested that the new power plants contributed $18.5 \%$ and $10 \%$ to the annual average $\mathrm{NO}_{2}$ columns in 2007 in Inner Mongolia and North China, respectively. The massive new power plant $\mathrm{NO}_{\mathrm{x}}$ emissions significantly changed the local $\mathrm{NO}_{2}$ profiles, especially in less polluted areas. A sensitivity study found that changes of $\mathrm{NO}_{2}$ shape factors due to including new power plant emissions increased the summer average OMI tropospheric $\mathrm{NO}_{2}$ columns by $3.8-17.2 \%$ for six selected locations, indicating that the updated emission information could help to improve the satellite retrievals.

\section{Introduction}

Nitrogen oxides $\left(\mathrm{NO}_{\mathrm{x}} \equiv \mathrm{NO}+\mathrm{NO}_{2}\right)$ play an important role in the photochemical production of tropospheric ozone and are detrimental to human health and the ecosystem. $\mathrm{NO}_{\mathrm{x}}$ is released to the troposphere as a result of anthropogenic (e.g., fossil-fuel and biofuel combustion and human-induced 
biomass burning) and natural (e.g., soil emissions, wildfires and lightning) phenomena. During the past two decades, anthropogenic $\mathrm{NO}_{\mathrm{x}}$ emissions from China have surged simultaneously with the rapid growth in China's economy and hence attract the attention of scientists and policy makers. Coalfired power plants are the largest coal consumer in China and are believed to be the largest contributor to China's $\mathrm{NO}_{\mathrm{x}}$ emissions (Hao et al., 2002; Zhang et al., 2007). Since 2005, hundreds of large electricity generator units have been constructed all over China. As a result, the total capacity of coalfired power plants has increased by $49 \%$, from $328 \mathrm{GW}$ in 2005 to 489 GW in 2007.

An understanding of the growth of power plant $\mathrm{NO}_{\mathrm{x}}$ emissions in China and subsequently a reliable evaluation of their environmental effects using atmospheric chemical models largely depends on how accurately we know the emission budget. $\mathrm{NO}_{\mathrm{x}}$ emission inventories are traditionally developed by integrating the emissions from all known source types using the fuel consumption data and emissions factors (e.g., Streets et al., 2003), which is the so-called bottom-up approach. China's coal-fired power plant $\mathrm{NO}_{\mathrm{x}}$ emissions have been estimated in many studies (Hao et al., 2002; Streets et al., 2003; Tian, 2003; Ohara et al., 2007; Zhang et al., 2007, 2009a; Zhao et al., 2008). However, the inaccurate information of the locations of power plants (except for Zhao et al., 2008), due to limited access to specific information about point sources in China, is always a defect for studies on individual power plant emissions and seems to lead to intrinsic regional discrepancies between modeled $\mathrm{NO}_{2}$ columns and satellite measurements over China (e.g., Zhao and Wang, 2009; Lin et al., 2010). Although the uncertainties in power plant emissions are believed to be far less than for other sources (Zhang et al., 2009a), reliable validation of the power plant $\mathrm{NO}_{\mathrm{x}}$ emissions with independent measurements is still a gap in China.

Remote sensing instruments provide valuable continuous observation data for tracing and evaluating $\mathrm{NO}_{\mathrm{x}}$ emissions from surface sources. During the past two decades, polar-orbiting satellite instruments such as the Global Ozone Monitoring Experiment (GOME), SCanning Imaging Absorption SpectroMeter for Atmospheric CHartographY (SCIAMACHY), Ozone Monitoring Instrument (OMI), and GOME-2, have sent back spatio-temporally continuous observations of the trace gases and aerosols in the atmosphere. These measurements greatly extended our insights into the temporal trends of atmospheric $\mathrm{NO}_{2}$ concentrations (e.g., Richter et al., 2005; van der A et al., 2008) and their atmospheric transport (e.g., Wenig et al., 2003), and were applied to derive "top-down" constraints on surface $\mathrm{NO}_{\mathrm{x}}$ emissions (Martin et al., 2003, 2006; Jaeglé et al., 2005; Konovalov et al., 2006; Wang et al., 2007; Lin et al., 2010, 2012; Lamsal et al., 2011) with the aid of chemical transport models.

With the improvement of the spatio-temporal resolution of satellite instruments, especially OMI, they have been proved to be capable in monitoring emissions from large point sources. Kim et al. $(2006,2009)$ found excellent correlations between the satellite measurements (SCIAMACHY and OMI) and WRF-Chem simulations over grids dominated by large power plants in the western United States, benefiting from the Continuous Emission Monitoring System (CEMS) data used in their studies. Carn et al. (2007) observed dense $\mathrm{SO}_{2}$ concentrations around the copper smelters in Peru using $\mathrm{OMI}$ and estimated their $\mathrm{SO}_{2}$ emissions. Ghude et al. (2008) identified major $\mathrm{NO}_{\mathrm{x}}$ emission hot spots in India using GOME and SCIAMACHY and analyzed the emission trends and seasonal cycle. In our previous work, we found that the dramatic changes of OMI-derived summertime $\mathrm{NO}_{2}$ and $\mathrm{SO}_{2}$ columns in Inner Mongolia, China, could be attributed to power plant construction activities and operation of fluegas desulfurization (FGD) devices (Zhang et al., 2009b; Li et al., 2010), and the growth rates of $\mathrm{NO}_{\mathrm{x}}$ emissions in the regions where new power plants were constructed could be even quantified by OMI observations (Wang et al., 2010). Lin and McElroy (2011) used thermal power generation (TPG) as the proxy of economy and found that the changes in OMI $\mathrm{NO}_{2}$ columns were consistent with changes in TPG. They further concluded that $\mathrm{OMI} \mathrm{NO}_{2}$ observations were capable of detecting the variations in $\mathrm{NO}_{\mathrm{x}}$ emissions stimulated by economy change. However, the contribution of power plants to the overall emission changes was not separated in their work.

In this work, we aim to portray an overall view of the changes of power plant $\mathrm{NO}_{\mathrm{x}}$ emissions in China during 2005-2007 based on bottom-up emission inventory and satellite observations, and evaluate their contributions to the growth of $\mathrm{NO}_{2}$ concentrations in China. Section 2 presents the methodology of the unit-based power plant emission inventory and the chemical transport model, as well as the OMI retrievals used in this study. We present the power plant $\mathrm{NO}_{\mathrm{x}}$ emissions in China in 2005-2007 in Sect. 3 and validate their accuracy using OMI measurements in Sect. 4. Section 5 portrays the growth of power plant $\mathrm{NO}_{\mathrm{x}}$ emissions viewed by $\mathrm{OMI}$ and quantifies their contributions to the growth of regional $\mathrm{NO}_{2}$ columns with GEOS-Chem. The impacts of the newly added power plant emissions on the a priori $\mathrm{NO}_{2}$ profiles used in the satellite retrievals are discussed in Sect. 6 . Section 7 summarizes the conclusions of this study.

\section{Methodology}

\subsection{Unit-based power plant emission inventory}

We develop a unit-based power plant $\mathrm{NO}_{\mathrm{x}}$ emission inventory for the time period of 2005-2007 for mainland China. Detailed information of $\sim 5700$ generator units was collected for this work, including geographical location, boiler size, coal consumption per unit electricity supply, emission 
control technology, and the exact month in which the unit formally came into operation and closed.

Monthly $\mathrm{NO}_{\mathrm{x}}$ emissions are calculated by each unit according to the technology and operation information, following the equation of Wang et al. (2010):

$E_{i}=\sum_{j} \sum_{k} \sum_{m} 1.4 \times U_{i, j} \times T_{i, j} \times F_{i} \times C_{i, j} \times E F_{k, m} \times 10^{-6}$

where $i, j, k, m$ stand for province, generator unit, boiler size, and emission control technology; 1.4 is the mass scaling factor from standard coal to raw coal; $E$ is the monthly $\mathrm{NO}_{\mathrm{x}}$ emissions ( $\mathrm{Mg}$ ); $U$ is the unit size (MW); $T$ is the annual operation hours; $F$ is the monthly fraction of annual total electricity generation; $C$ is the specific coal consumption per unit electricity supply (gram coal equivalent $\mathrm{kWh}^{-1}$ ); and $E F$ is the emission factor $\left(\mathrm{g} \mathrm{kg}^{-1}\right)$. The dynamical $\mathrm{NO}_{\mathrm{x}}$ emission factors adopted from Zhang et al. (2007) vary between 5.6 and $10.5 \mathrm{~g} \mathrm{~kg}^{-1}$ coal burned based on boiler size and the presence or absence of low- $\mathrm{NO}_{\mathrm{x}}$-burner (LNB), which are comparable to the values of $4.0-11.5 \mathrm{~g} \mathrm{~kg}^{-1}$ used in Zhao et al. (2008).

\subsection{GEOS-Chem Model}

We simulate tropospheric $\mathrm{NO}_{2}$ columns over China for the years 2005-2007 using the nested-grid GEOS-Chem model. The GEOS-Chem model is a global 3-D chemical transport model (CTM) for atmospheric composition including a detailed simulation of tropospheric ozone- $\mathrm{NO}_{\mathrm{x}}$-hydrocarbon chemistry as well as of aerosols and their precursors (Bey et al., 2001). The chemical mechanism includes $>80$ species and $>300$ reactions. The GEOS-Chem model is driven by assimilated meteorological fields from the Goddard Earth Observing System (GEOS) at the NASA Global Modeling and Assimilation Office (GMAO: http://gmao.gsfc.nasa.gov/). In this paper we use the nested-grid GEOS-Chem model (v802-01) developed by Chen et al. (2009) with GEOS-5 at native horizontal resolution of $0.5^{\circ} \times 0.667^{\circ}$. The nested-grid GEOS-Chem model is embedded into the coarse-resolution global model $\left(4^{\circ} \times 5^{\circ}\right)$ through the one-way nested approach, propagating the time-varying boundary conditions from the global model with consistent meteorology, dynamics, and chemistry. The nested domain stretches from $11^{\circ} \mathrm{S}$ to $55^{\circ} \mathrm{N}$ and from $70^{\circ} \mathrm{E}$ to $150^{\circ} \mathrm{E}$, covering most of East/Southeast Asia. GEOS-5 meteorological data are provided every 3-6 h ( $3 \mathrm{~h}$ for surface fields and mixing depths) for 72 hybrid pressure sigma levels in the vertical extending up to $0.01 \mathrm{hPa}$. For computational expedience the vertical levels above the lower stratosphere are merged, retaining a total of 47 vertical levels, with 14 pure sigma levels resolved within $2 \mathrm{~km}$ altitude. In this work, we conduct 3-yr full-chemistry simulations for 2005-2007.
The global anthropogenic emissions are from EDGAR (Olivier and Berdowski, 2001) for the base year of 2000 and scaled to 2006 following van Donkelaar et al. (2008). We then replaced the anthropogenic $\mathrm{NO}_{\mathrm{x}}$ emission inventory over China with our own estimates. For power plant emissions we use the unit-based inventory for 2005-2007 described in Sect. 2.1. Other anthropogenic $\mathrm{NO}_{\mathrm{x}}$ emissions and monthly variations were developed for the years 2005-2007 following the methodology described in Zhang et al. (2007), with dynamic emission factors to reflect the technology innovations. Emissions for other parts of East/Southeast Asia are replaced by the INTEX-B inventory for 2006 (Zhang et al., 2009a). The GEOS-Chem model also includes $\mathrm{NO}_{\mathrm{x}}$ emissions from soils (Yienger and Levy, 1995; Wang et al., 1998), lightning (Sauvage et al., 2007), biomass burning (van der Werf et al., 2006), biofuel (Yevich and Logan, 2003), aircraft (Baughcum et al., 1996), and stratospheric flux. Table 1 summarizes the $\mathrm{NO}_{\mathrm{x}}$ emissions over China used in this work.

A 1-yr spin-up was conducted to remove the effects of the initial concentration fields. Monthly varying tropopause heights were used to derive the tropospheric $\mathrm{NO}_{2}$ columns. Daily 2-h early afternoon modeled tropospheric $\mathrm{NO}_{2}$ columns were averaged at the local time of 13:00-15:00 h. To be consistent with the OMI observations, we sampled the model at grids coincident with the daily satellite pixels used in the final average columns.

\subsection{OMI tropospheric $\mathrm{NO}_{2}$ column densities}

The OMI aboard the Aura satellite is a nadir-viewing imaging spectrograph measuring the earthshine radiance and the solar irradiance in the ultraviolet-visible range from 264 to $504 \mathrm{~nm}$ (Levelt et al., 2006). The Aura spacecraft, the last of the EOS observatories, was launched on 15 July 2004, into a sun-synchronous polar orbit at $705 \mathrm{~km}$ altitude with a $98.2^{\circ}$ inclination and a local equator-crossing time of $13: 45 \mathrm{~h}$ in ascending node. OMI measures the complete spectrum with the nadir pixel size of $24 \times 13 \mathrm{~km}^{2}$ and daily global coverage.

The $\mathrm{NO}_{2}$ abundance is quantified along the viewing path (slant column) using DOAS (Differential Optical Absorption Spectroscopy) (Platt, 1994; Boersma et al., 2002; Bucsela et al., 2006) for each pixel. The air mass factor (AMF), defined as the ratio of the slant column abundance to the vertical column abundance, can be formulated as the integral of the relative vertical distribution (shape factors), weighted by altitude-dependent coefficients (scattering weight factors) for optically thin atmospheric species (Palmer et al., 2001).

In this work, the tropospheric slant $\mathrm{NO}_{2}$ column densities are from the DOMINO product (version 1.0.2, collection 3) (Boersma et al., 2007) available from the Tropospheric Emission Monitoring Internet Service (TEMIS) (http://www.temis.nl/). The tropospheric slant column density is obtained by removing the stratospheric contribution estimated from assimilating slant columns provided by a global CTM, the TM4 model (Dirksen et al., 2011). The 
Table 1. A priori annual GEOS-Chem $\mathrm{NO}_{\mathrm{x}}$ emissions in 20052007 in mainland China.

\begin{tabular}{lrrr}
\hline Source & \multicolumn{3}{c}{$\begin{array}{c}\text { Annual Emissions } \\
\left(\mathrm{Tg} \mathrm{NO}_{2}\right)\end{array}$} \\
\cline { 2 - 4 } & 2005 & 2006 & 2007 \\
\hline Power plants & 8.11 & 8.92 & 9.58 \\
Other anthropogenic sources* & 10.69 & 11.78 & 13.77 \\
Biomass burning & 0.15 & 0.20 & 0.23 \\
Soils and fertilizers & 1.71 & 1.75 & 1.77 \\
Lightning & 0.83 & 0.90 & 0.59 \\
Aircraft & 0.05 & 0.05 & 0.05 \\
\hline
\end{tabular}

*Including industry, transportation, and biofuel $\mathrm{NO}_{\mathrm{x}}$ emissions.

cross-track biases were then determined using the average $\mathrm{NO}_{2}$ slant column densities in the 5th to 95th percentile limits over less polluted areas $\left(30^{\circ} \mathrm{S}-5^{\circ} \mathrm{N}\right)$ and removed from the tropospheric slant column densities for each orbit dataset, following the approach described by Celarier et al. (2008) and Lamsal et al. (2010). Correction of the cross-track bias is estimated to cause $\sim 5 \%$ decrease in the average tropospheric $\mathrm{NO}_{2}$ column (Lamsal et al., 2010).

The tropospheric vertical $\mathrm{NO}_{2}$ column retrieval is sensitive to the a priori $\mathrm{NO}_{2}$ shape factors. Lamsal et al. (2010) developed an alternative OMI product (DP_GC) based on the DOMINO product and validated its accuracy in summer using in-situ measurements carried out in the United States. They used $\mathrm{NO}_{2}$ shape factors generated from GEOS-Chem $\left(2^{\circ} \times 2.5^{\circ}\right.$ with GEOS-4 meteorology fields $)$ in DP_GC and Average Kernels $\left(A_{k}\right)$ from the DOMINO product to reproduce the AMF for each OMI pixel in order to improve the representation in $\mathrm{NO}_{2}$ shape factors generated by TM4, which have been found to be insufficiently mixed throughout the boundary layer due to the inconsistency in model sampling (Hains et al., 2010; Boersma et al., 2011) and to ensure self-consistency when compared the OMI retrievals with GEOS-Chem modeled columns (Eskes and Boersma, 2003; Boersma et al., 2004).

In this work, we follow the method in Lamsal et al. (2010) but use $\mathrm{NO}_{2}$ shape factors provided by the nested-grid GEOS-Chem simulation described in Sect. 2.2 to calculate the local AMF. The high-resolution shape factors $\left(0.5^{\circ} \times\right.$ $0.666^{\circ}$ ) simulated with year-by-year emission inputs improve the representation of the real vertical distributions in OMI pixels and also consider changes in the $\mathrm{NO}_{2}$ shape factors related to the changes of $\mathrm{NO}_{\mathrm{x}}$ emissions. The effects of newly added power plant emissions on $\mathrm{NO}_{2}$ shape factors and OMI retrievals will be discussed in Sect. 6 .

We used only OMI pixels with solar zenith angle $\leq 70^{\circ}$ and cloud radiance fraction $\leq 0.3$ in the final average columns. Pixels at swath edges (five pixels on each side) were rejected to reduce spatial averaging. Since 25 June 2007 the cross-track positions 53-54 (0-based) in the OMI data are specified as a row anomaly due to the effect of a partial external blockage of the radiance port on the instrument (http://www.knmi.nl/omi/research/ product/rowanomaly-background.php). These affected pixels were removed. Finally, each OMI pixel was allocated by area-weights into $0.5^{\circ} \times 0.667^{\circ}$ grids with corner coordinate information to achieve daily global tropospheric vertical $\mathrm{NO}_{2}$ column maps.

\section{Power plant $\mathrm{NO}_{\mathrm{x}}$ emissions in China, 2005-2007}

\subsection{New power plants}

We refer to the power plants with generator units coming into operation in 2005-2007 hereinafter as "new power plants" in this paper. The total capacities of coal-fired power generation have increased by $48.8 \%$, from $328.4 \mathrm{GW}$ at the beginning of 2005 to $488.8 \mathrm{GW}$ at the end of 2007 . The new generator units are mainly concentrated in five provinces (see Table 2), which are Inner Mongolia (18.6 GW), Jiangsu (17.3 GW), Zhejiang (12.5 GW), Shandong (12.2 GW), and Henan $(11.2 \mathrm{GW})$, accounting for $45.0 \%$ of the total capacity additions.

Why have new power plants surged in just two years? Rapid development of the economy and high energyconsuming industry contributed to a shortage of electricity generation in the first few years of this century in China. As a result, as many as 22 provinces in China limited their electricity supply to some extent in 2003. In this context, a batch of large generator units was immediately licensed for construction and consequently came into operation during 20052007.

Most of the new generator units are large. Figure 1 shows the changes of total capacities for different sizes of generator units in 2004-2007. The capacities of generator units with size $<300 \mathrm{MW}$ are $171.3 \mathrm{GW}$ in 2004 , and remain almost constant in magnitude for the following three years. In contrast, $92.2 \%$ of the total capacity additions in 20052007 are from generator units with size $\geq 300 \mathrm{MW}$. This reflects the huge electricity demand and also corresponds to a structural readjustment in the power sector aimed at energy conservation and emission reduction. It is noteworthy that generator units with size $\geq 600 \mathrm{MW}$ began to come into operation throughout the country since 2006 , with total capacity increasing from $38.8 \mathrm{GW}$ at the beginning of 2005 to $132.4 \mathrm{GW}$ at the end of 2007, a factor of 3.4. As a result, the proportion of generator units with size $<300 \mathrm{MW}$ decreased from $52.2 \%$ in 2004 to $37.6 \%$ at the end of 2007 .

\subsection{Power plant $\mathrm{NO}_{\mathrm{x}}$ emissions}

As a consequence of the new power plant construction, annual power plant $\mathrm{NO}_{\mathrm{x}}$ emissions increased from $8.11 \mathrm{Tg}$ in 2005 to $9.58 \mathrm{Tg}$ in 2007 in China, based on our unitbased power plant $\mathrm{NO}_{\mathrm{x}}$ emission inventory. Figure 2 shows 
Table 2. Annual and summer (June to August) $\mathrm{NO}_{\mathrm{x}}$ emissions from coal-fired power plants in 2005-2007 in mainland China.

\begin{tabular}{|c|c|c|c|c|c|c|c|}
\hline \multirow[b]{3}{*}{ Region } & \multicolumn{6}{|c|}{$\mathrm{NO}_{\mathrm{x}}$ Emissions $\left(\mathrm{Gg} \mathrm{NO}_{2} \mathrm{a}^{-1}\right)$} & \multirow{3}{*}{$\begin{array}{r}\text { New } \\
\text { Capacities* }^{*} \\
(\mathrm{MW})\end{array}$} \\
\hline & \multicolumn{2}{|c|}{2005} & \multicolumn{2}{|c|}{2006} & \multicolumn{2}{|c|}{2007} & \\
\hline & Annual & Summer & Annual & Summer & Annual & Summer & \\
\hline Anhui & 222.3 & 61.8 & 243.8 & 70.7 & 270.4 & 76.0 & 6860 \\
\hline Beijing & 82.4 & 22.0 & 73.9 & 17.9 & 75.6 & 20.1 & 0 \\
\hline Chongqing & 79.2 & 17.3 & 100.7 & 25.3 & 117.3 & 24.6 & 2700 \\
\hline Fujian & 144.7 & 32.1 & 157.8 & 34.2 & 199.6 & 52.1 & 4800 \\
\hline Gansu & 123.0 & 28.9 & 124.0 & 27.1 & 144.2 & 30.8 & 2150 \\
\hline Guangdong & 467.6 & 114.1 & 510.5 & 123.0 & 561.7 & 155.8 & 8910 \\
\hline Guangxi & 110.2 & 22.9 & 114.5 & 22.0 & 125.9 & 24.5 & 1800 \\
\hline Guizhou & 245.0 & 63.7 & 292.8 & 73.3 & 302.6 & 71.0 & 5500 \\
\hline Hainan & 17.7 & 5.1 & 19.0 & 5.5 & 24.2 & 7.2 & 660 \\
\hline Hebei & 517.3 & 137.8 & 519.6 & 139.1 & 559.6 & 142.5 & 6730 \\
\hline Heilongjiang & 300.8 & 68.4 & 332.6 & 77.0 & 325.4 & 80.5 & 3115 \\
\hline Henan & 637.3 & 168.2 & 650.4 & 171.2 & 725.2 & 180.3 & 11210 \\
\hline Hubei & 209.3 & 53.9 & 243.1 & 63.9 & 257.2 & 60.9 & 2600 \\
\hline Hunan & 127.6 & 33.8 & 174.5 & 45.0 & 183.5 & 40.9 & 5450 \\
\hline Inner Mongolia & 452.6 & 100.6 & 584.3 & 138.3 & 684.2 & 167.6 & 18574 \\
\hline Jiangsu & 748.8 & 205.3 & 800.2 & 217.0 & 817.0 & 221.5 & 17335 \\
\hline Jiangxi & 137.2 & 35.0 & 139.6 & 35.1 & 148.8 & 40.7 & 3330 \\
\hline Jilin & 209.3 & 46.4 & 229.3 & 56.7 & 234.3 & 59.0 & 2260 \\
\hline Liaoning & 389.2 & 92.4 & 424.8 & 108.9 & 438.1 & 109.2 & 4270 \\
\hline Ningxia & 110.9 & 26.2 & 132.4 & 37.2 & 147.5 & 34.0 & 3180 \\
\hline Qinghai & 26.4 & 6.3 & 32.3 & 7.7 & 36.0 & 8.3 & 0 \\
\hline Shaanxi & 191.9 & 41.5 & 208.2 & 53.2 & 235.5 & 57.1 & 4530 \\
\hline Shandong & 861.3 & 226.3 & 925.4 & 242.5 & 974.8 & 258.7 & 12240 \\
\hline Shanghai & 187.9 & 50.1 & 181.1 & 50.1 & 180.7 & 48.1 & 0 \\
\hline Shanxi & 496.0 & 130.3 & 540.0 & 136.1 & 567.6 & 143.2 & 9500 \\
\hline Sichuan & 248.8 & 60.0 & 267.3 & 71.3 & 252.4 & 51.0 & 4290 \\
\hline Tianjin & 116.6 & 31.2 & 114.1 & 29.0 & 120.3 & 34.8 & 600 \\
\hline Tibet & 0 & 0 & 0 & 0 & 0 & 0 & 0 \\
\hline Xinjiang & 126.7 & 34.7 & 142.7 & 37.9 & 157.6 & 42.3 & 890 \\
\hline Yunnan & 147.4 & 32.0 & 194.9 & 43.7 & 205.3 & 45.9 & 5400 \\
\hline Zhejiang & 370.6 & 96.0 & 442.2 & 111.6 & 503.6 & 140.5 & 12505 \\
\hline China Total & 8105.6 & 2044.6 & 8916.1 & 2271.6 & 9576.3 & 2429.1 & 161389 \\
\hline
\end{tabular}

*Capacities of new generator units which came into operation in 2005-2007.

the spatial distributions of annual power plant $\mathrm{NO}_{\mathrm{x}}$ emissions for 2005 and 2007 and the changes. The changes shown in Fig. 2c clearly illustrate the locations of the new power plants and magnitudes of their $\mathrm{NO}_{\mathrm{x}}$ emissions. Table 2 summarizes the annual and summer (June-August) power plant $\mathrm{NO}_{\mathrm{x}}$ emissions by province for 2005-2007 in mainland China. The growth rate of $\mathrm{NO}_{\mathrm{x}}$ emissions between 2005 and 2007 in the power sector $(18.1 \%)$ is less than the growth rates of total capacity $(48.8 \%)$ and coal consumption $(26.5 \%)$ in coal-fired power plants, reflecting improvements in energy efficiency and emission control technology in new generator units and reduced annual operating hours. The $\geq 600 \mathrm{MW}$ generator units contribute $27.1 \%$ to capacity, consume $20.7 \%$ of the coal, and release $16.0 \%$ of the power plant $\mathrm{NO}_{\mathrm{x}}$ to the atmosphere in 2007. In contrast, the $\leq 100 \mathrm{MW}$ generator units contribute $16.8 \%$ to capacity, but consume $23.2 \%$ of the coal, and emit $32.8 \%$ of the power plant $\mathrm{NO}_{\mathrm{x}}$ in 2007. Though emissions generally increase throughout the country, as revealed by Fig. 2, Beijing and Shanghai show downward trends because of the migration of coal-fired power plants away from these two metropolitan areas.

The 2006 annual emissions are within $3 \%$ of the $9.20 \mathrm{Tg}$ estimate in the INTEX-B emissions inventory (Zhang et al., 2009a), because of the similar province activity data and emission factors used in these two inventories. Our annual power plant $\mathrm{NO}_{\mathrm{x}}$ emission estimates for 2005 are $16 \%$ higher than the value of $6.97 \mathrm{Tg}$ in another unit-based power plant inventory (Zhao et al., 2008). This difference could be 


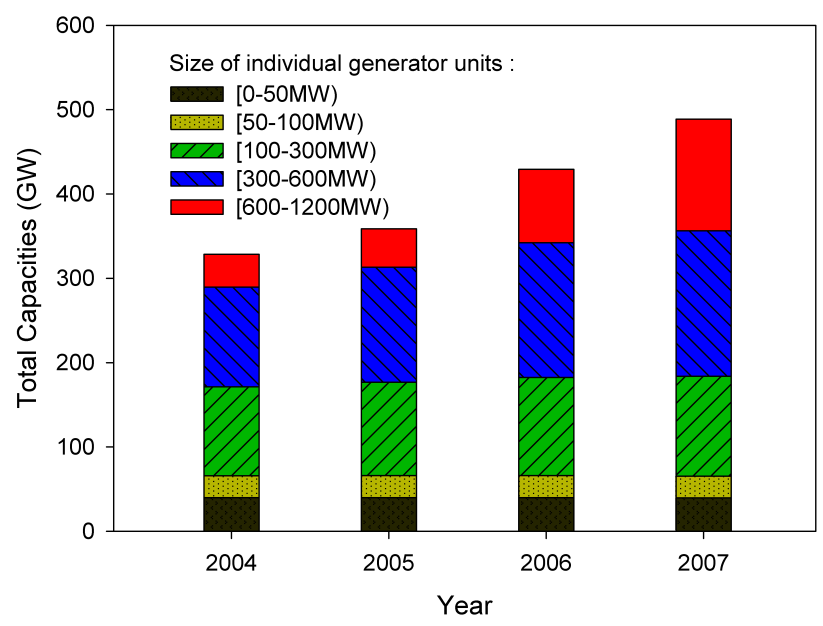

Fig. 1. Changes of total capacities for different sizes of coal-fired generator units in 2004-2007 in China.

attributed to the use of different emission factors in the two inventories.

Using a Monte-Carlo approach described in Zhao et al. (2011), the average uncertainty of this inventory is estimated to be $-20 \%$ to $19 \%$ (at $95 \%$ coincident intervals). Also the uncertainties related to geographical location have been significantly reduced in our unit-based power plant emission inventory compared to previous "bottom-up" estimates. However, uncertainty for an individual unit could be larger because unified emission factors and annual operation hours were applied to group of units. In the US, $\mathrm{NO}_{\mathrm{x}}$ emission rates for most power plants are measured by CEMS, which represent one of the most accurate parts of the US emission database, but this is not the case for China. Average emission factors from limited local measurements were used for all generator units with similar technologies, which ignored possible variations among individual units and will introduce some uncertainties. Also, the monthly profile was calculated for each province using the monthly fraction of annual total electricity generation and applied to all generator units in the province. This algorithm will not affect the total $\mathrm{NO}_{\mathrm{x}}$ emission budget but downgrade the accuracy for individual plant estimates, as it misses the variations of operating conditions among individual generator units. We estimate a typical uncertainty level of $-42 \%$ to $51 \%$ for an individual unit by using Monte-Carlo approach.

\section{Evaluation of power plant $\mathrm{NO}_{\mathrm{x}}$ inventory by OMI observations}

Power plants in China are often located in populated areas where there is a mix of various anthropogenic $\mathrm{NO}_{\mathrm{x}}$ sources, such as industrial complexes and vehicles, which adds difficulties to the validation of power plant emissions. To further investigate the impact of the uncertainties associated with
Table 3. Reduced Major Axis regression analysis between OMI ( $\mathrm{x}$ axis) and GEOS-Chem (y-axis) summer (June to August) average $\mathrm{NO}_{2}$ columns in 2005 and 2007.

\begin{tabular}{llrrr}
\hline Date & Regression & Case A & Case B & Case C \\
\hline \multirow{3}{*}{ 2005-JJA } & Slope & 0.86 & 0.74 & 0.75 \\
& Offset & 0.06 & 0.06 & -0.03 \\
& $R^{2}$ & 0.82 & 0.78 & 0.85 \\
& Samples* & 106 & 615 & 2968 \\
\hline \multirow{3}{*}{ 2007-JJA } & Slope & 0.93 & 0.89 & 0.83 \\
& Offset & -0.25 & -0.35 & -0.13 \\
& $R^{2}$ & 0.79 & 0.62 & 0.74 \\
& Samples* & 125 & 556 & 2851 \\
\hline
\end{tabular}

*Only grids with OMI sample number $\geq 10$ are used.

other anthropogenic emissions on the evaluation of the power plant inventory, we compare the modeled and observed $\mathrm{NO}_{2}$ columns over three categories of grids in China as the following three cases: grids dominated by power plant $\mathrm{NO}_{\mathrm{x}}$ emissions (Case A), all grids with power plants (Case B), and all grids in China (Case C). Case A is defined as grids with urban population $<0.5$ million and power plant $\mathrm{NO}_{\mathrm{x}}$ emissions $>60 \%$ of total $\mathrm{NO}_{\mathrm{x}}$ emissions. The urban population data are obtained by masking the LandScan $20061 \mathrm{~km} \times 1 \mathrm{~km}$ resolution population density (Bhaduri et al., 2002) using Moderate Resolution Imaging Spectroradiometer (MODIS) urban land use fraction data (Schneider et al., 2009) and then degraded to $0.5^{\circ} \times 0.667^{\circ}$ resolution. Grids with urban population $<0.5$ million are generally associated with rural areas or small towns in China.

The modeled summer average tropospheric $\mathrm{NO}_{2}$ columns are compared with OMI measurements for the three cases in Figs. 3-5 and Table 3. We only used summer data for comparison, as $\mathrm{NO}_{2}$ columns have a closer relationship to local emissions in summer than other seasons due to the shorter lifetime of $\mathrm{NO}_{\mathrm{x}}$ in summer. However, South China and the Sichuan Basin are frequently covered by cloud in summer, resulting in insufficient observation samples in these regions (see Fig. 7). We use only grids with OMI sample number $\geq 10$ to conduct the validation in those regions.

Figure 3 presents the relationship between model and OMI $\mathrm{NO}_{2}$ columns over the grids where power plant emissions are dominant (Case A) for 2005 and 2007. The grids are colored by the regions defined in Fig. 2. Only $\sim 4 \%$ of total samples over China were left (see Table 3) after using the filtering criterion described above. As presented in Table 3, modeled columns are 7-14\% lower than OMI retrievals, within the uncertainty range of the power plant emission estimates. The spatial correlations are high $\left(R^{2}=0.79-0.82\right)$ with little scatter, lending support to the high accuracy of the unitbased power plant $\mathrm{NO}_{\mathrm{x}}$ emission inventory. Also it should be noted that emissions in the power plant dominant grids are represented by total $\mathrm{NO}_{\mathrm{x}}$ emissions, including other 
(a) 2005

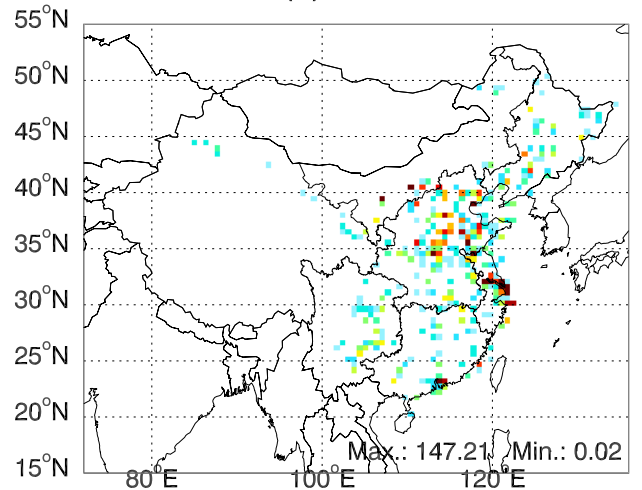

(b) 2007

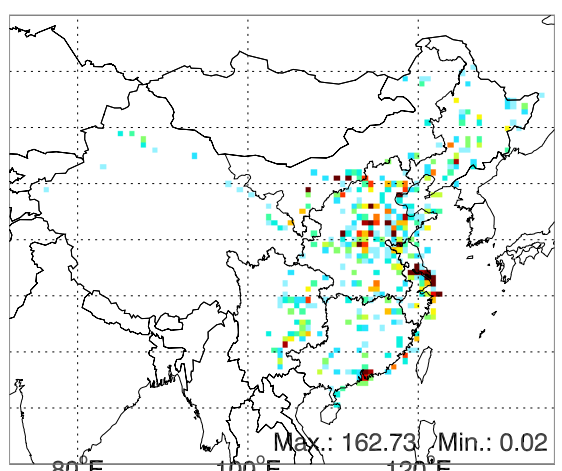

$80 \mathrm{E}$ (c) 2007 minus 2005

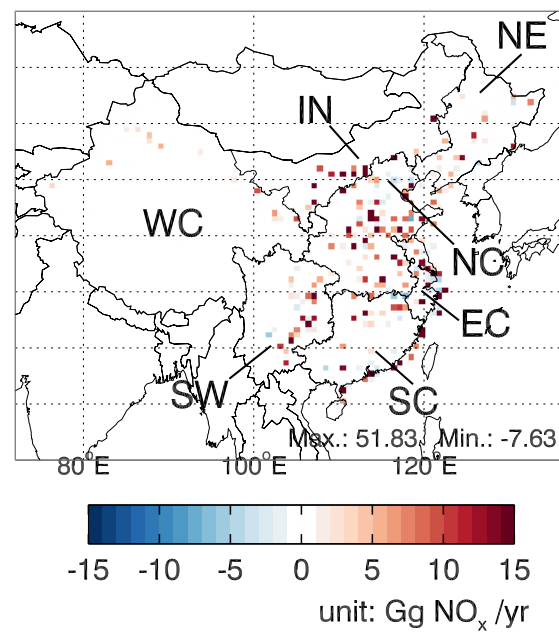

Fig. 2. Spatial distributions of annual coal-fired power plant $\mathrm{NO}_{\mathrm{x}}$ emissions for 2005 and 2007 and the changes. The maximum values and minimum values are indicated. Solid lines within the Chinese national boundaries denote the seven regions discussed in the text: NENortheast China, IN-Inner Mongolia, NC-North China, EC-East China, SC-South China, SW-Southwest China, and WC-West China.
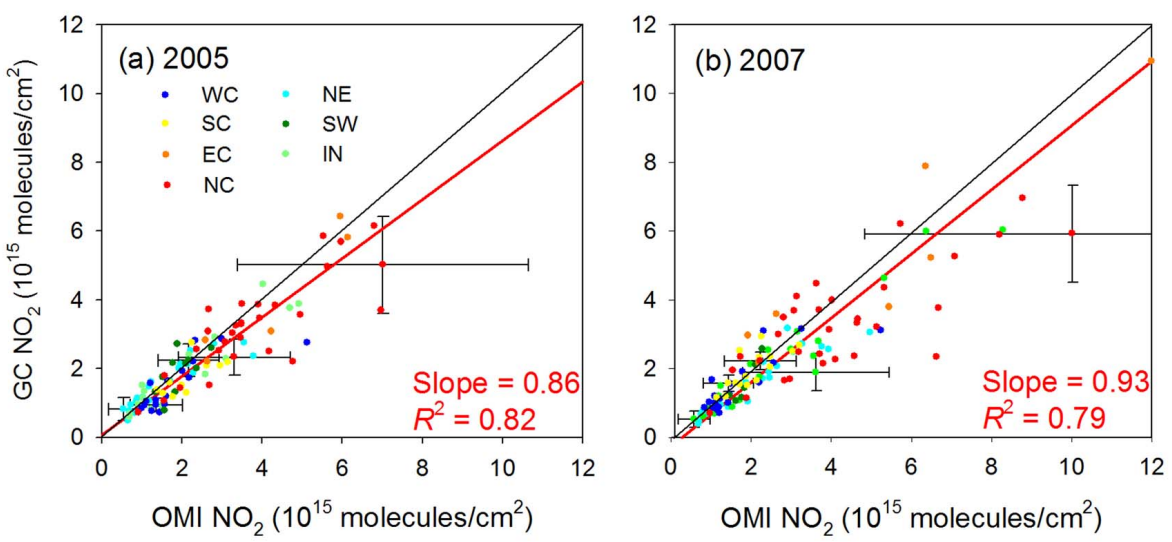

Fig. 3. Comparisons between GEOS-Chem and OMI summer average tropospheric $\mathrm{NO}_{2}$ columns for (a) 2005 and (b) 2007 over power plant dominant grids in China. Grids are colored by the regions defined in Fig. 2. The linear fit regression (red line) is based on Reduced Major Axis (RMA) algorithm (Clarke, 1980). Error bars indicate the standard deviations in the summer average columns (only shown for minimum, quartiles, and maximum points in OMI datasets).

anthropogenic emissions, and remotely sensed urban extent, which may or may not be accurate. In previous work it has been concluded that anthropogenic $\mathrm{NO}_{\mathrm{x}}$ emission estimates for industry and transportation can be significantly underestimated for a specific grid (Zhang et al., 2007; Wang et al., 2010). This probably causes the significant low bias of the modeled $\mathrm{NO}_{2}$ columns for several grids in North China (see Fig. 3b), where emissions from industries and vehicles are high. Using a threshold in which power plant $\mathrm{NO}_{\mathrm{x}}$ emissions exceed $80 \%$ of total $\mathrm{NO}_{\mathrm{x}}$ emissions (instead of $60 \%$ ) further improves the $R^{2}$ to $0.77-0.91$ and slopes to $0.89-0.97$, but with only $<1 \%$ samples remaining.

Excellent correlations between WRF-Chem modeled and satellite based $\mathrm{NO}_{2}$ columns over power plant plumes were also observed in western United States regions dominated by power plant $\mathrm{NO}_{\mathrm{x}}$ emissions (Kim et al., 2006, 2009). Those good agreements were partly benefited from the highly accurate $\mathrm{NO}_{\mathrm{x}}$ emission data measured by CEMS. In this work, although our unit-based power plant $\mathrm{NO}_{\mathrm{x}}$ emission estimates for individual generator units would not have accuracy as high as CEMS measurements, the similar excellent agreements between model and $\mathrm{OMI} \mathrm{NO} 2$ columns (slope $=0.86-$ $0.93, R=0.89-0.90$ ) may support reasonably high accuracy of our emission estimates. Considering the uncertainties in bottom-up inventories (Zhao et al., 2011), satellite retrievals (Boersma et al., 2004), and the coarse resolution of GEOSChem compared to the original fine footprint of OMI, we can 

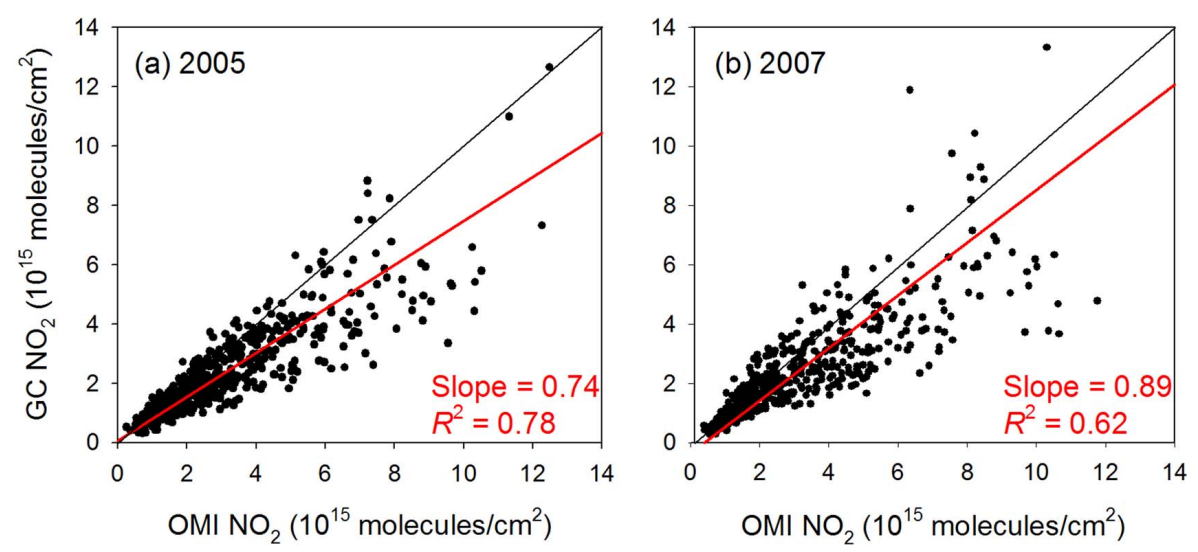

Fig. 4. Comparisons between GEOS-Chem and OMI summer average tropospheric $\mathrm{NO}_{2}$ columns for (a) 2005 and (b) 2007 over grids with power plants in China. RMA algorithm is used in the linear fitting (red line).
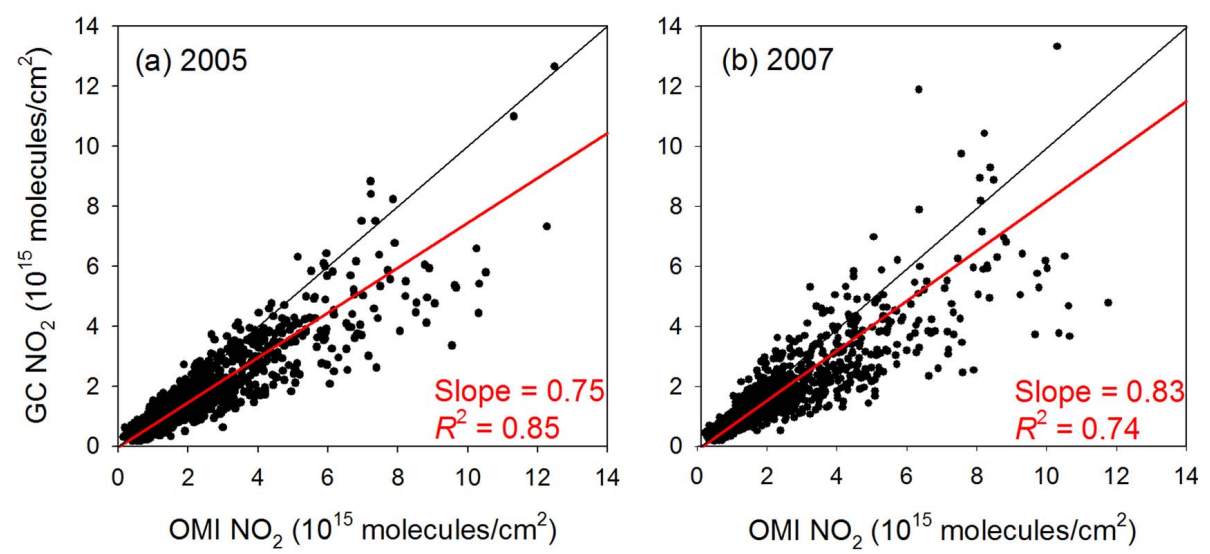

Fig. 5. Comparisons between GEOS-Chem and OMI summer average tropospheric $\mathrm{NO}_{2}$ columns for (a) 2005 and (b) 2007 over all grids in China. RMA algorithm is used in the linear fitting (red line).

conclude that the unit-based power plant $\mathrm{NO}_{\mathrm{x}}$ emissions developed in this work are reasonably reliable.

We next plotted the correlations between modeled and OMI observed $\mathrm{NO}_{2}$ columns for all grids with power plant $\mathrm{NO}_{\mathrm{x}}$ emissions (Case B) in Fig. 4, which include $\sim 20 \%$ of the total samples over China (see Table 3). Compared with Case A, the $R^{2}$ values decreased to $0.62-0.78$ with considerable scatter observed in grids with elevated $\mathrm{NO}_{2}$ concentrations, indicating that total $\mathrm{NO}_{\mathrm{x}}$ emissions are relatively poorly understood over regions where power plant emissions are mixed with other anthropogenic sources. Other anthropogenic emission inventories used in this work are thought to be much more uncertain than the unit-based power plant inventory, as they were estimated at provincial level and then allocated to each grid using various spatial proxies such as population density and road networks (Streets et al., 2003). The uncertainties induced by this "top-down" assignment method could be large for a specific grid, which may result in relatively poor model performance over many grids. However, assessing the uncertainties introduced by the emission gridding process is beyond the scope of this paper and will need to be investigated in future work.

Tropospheric $\mathrm{NO}_{2}$ columns over all grids in China (Case C) also have good spatial correlations between model and OMI with $R^{2}$ of 0.85 and 0.74 for 2005 and 2007 respectively, as shown in Fig. 5. Modeled $\mathrm{NO}_{2}$ columns are 17$25 \%$ lower than OMI, with more significant biases and scatter over high concentration regions. This bias in modeled $\mathrm{NO}_{2}$ columns shown here is better than biases of more than $50 \%$ in previous studies that used the GEOS-Chem model (e.g., Martin et al., 2006; Lin et al., 2010). The improvement of model performance here can be partly attributed to the more accurate power plant $\mathrm{NO}_{\mathrm{x}}$ emissions: the underestimation of modeled columns increased to $29 \%$ in a sensitivity run with power plant emissions from the INTEX-B inventory (Zhang et al., 2009a) instead of the unit-based inventory. The finer model resolution may also play an important role.

Figure 6 shows the OMI and GEOS-Chem tropospheric $\mathrm{NO}_{2}$ columns for the summers of 2005 and 2007 over China and their differences. Both model and OMI maps illustrate 

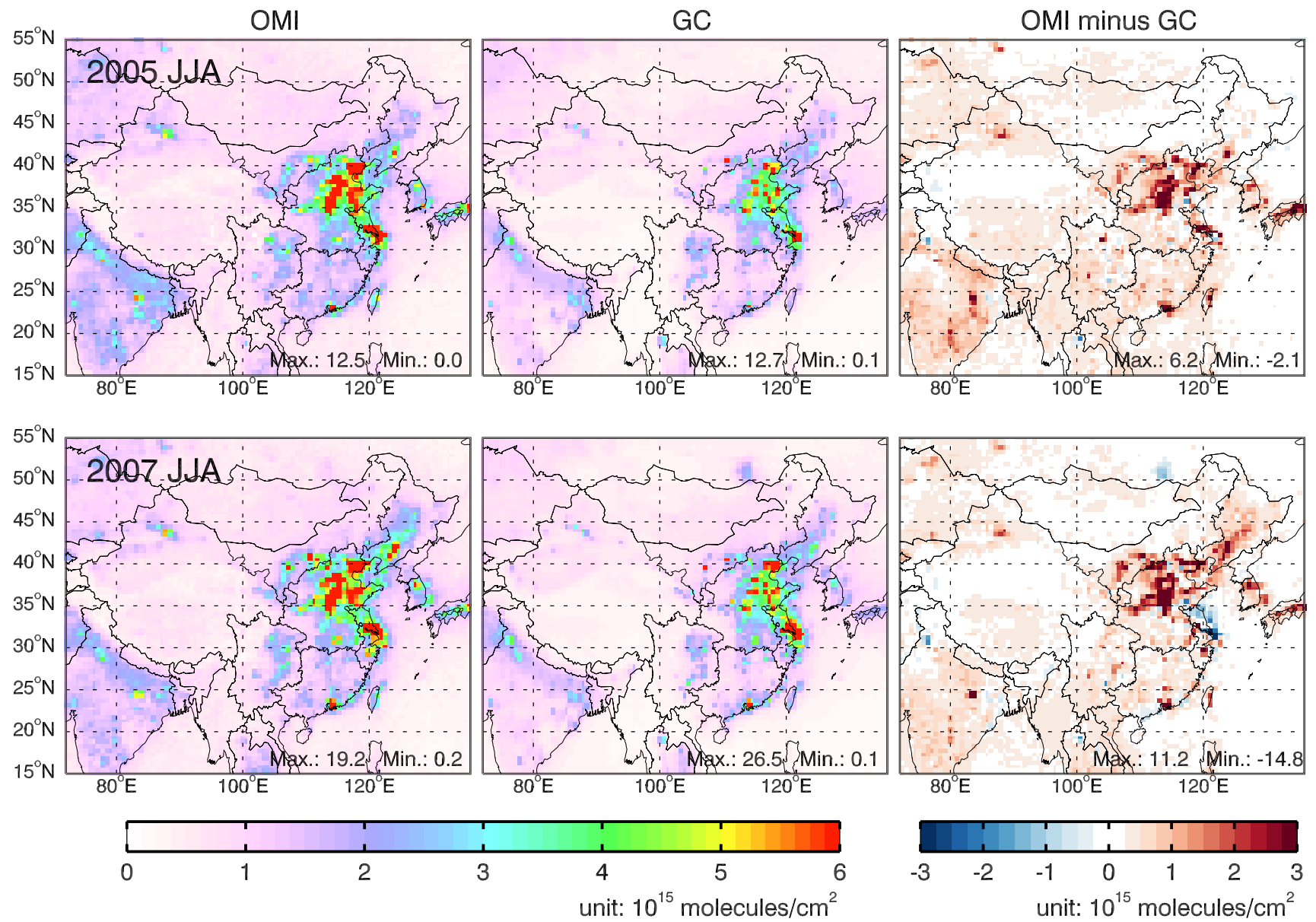

Fig. 6. OMI and GEOS-Chem tropospheric $\mathrm{NO}_{2}$ columns for summers (JJA) of 2005 (top) and 2007 (bottom) and their differences.

that $\mathrm{NO}_{\mathrm{x}}$ emissions are concentrated in areas with dense energy consuming sources in eastern of China. Isolated metropolitan areas in northeastern and southeastern parts of China can be identified easily by OMI. Some individual large power plants located in rural areas are also obvious. However, the modeled $\mathrm{NO}_{2}$ columns are significantly lower than OMI measurements by a factor of 2-3 in Shanxi-ShaanxiInner Mongolia region, where there are large coal reserves and many power plants and energy-consuming industrial complexes were built during the past decade. As power plant emissions can be well constrained by OMI, this difference possibly points to missing $\mathrm{NO}_{\mathrm{x}}$ emissions from other energyintensive industries, which are widespread in these regions but are not well represented in the current bottom-up emission inventory and need to be further investigated (Zhang et al., 2009b). Another possible source of bias could come from errors in simulating $\mathrm{NO}_{\mathrm{x}}$ chemistry (Valin et al., 2011).
5 Increases of power plant $\mathrm{NO}_{\mathrm{x}}$ emissions in 2005-2007

\subsection{Satellite observations of $\mathrm{NO}_{\mathrm{x}}$ emissions from new power plants}

Figure $7 \mathrm{a}, \mathrm{b}$ show the ratios of annual and summer average tropospheric $\mathrm{NO}_{2}$ columns between 2007 and 2005 from OMI, respectively. The two small maps below each ratio map present the sample amounts used in the averages for the corresponding years. The new power plants are indicated as open circles in Fig. 7 (only the units coming into operation between June 2005 and August 2007 are plotted in Fig. 7b), with three symbol sizes from small to large indicating the total capacities of new generator units $(<500 \mathrm{MW}, 500$ $1200 \mathrm{MW},>1200 \mathrm{MW}$ ) in the corresponding power plants. The ratios are unreliable in background regions due to noise in satellite observations so that only those grids with average $\mathrm{NO}_{2}$ columns $>1.0 \times 10^{15}$ molecules $\mathrm{cm}^{-2}$ in both years are colored in the ratio maps.

Most of the distinct increases of $\mathrm{NO}_{2}$ columns viewed by OMI during the two years are found to be collocated with 
(a) Annual Average
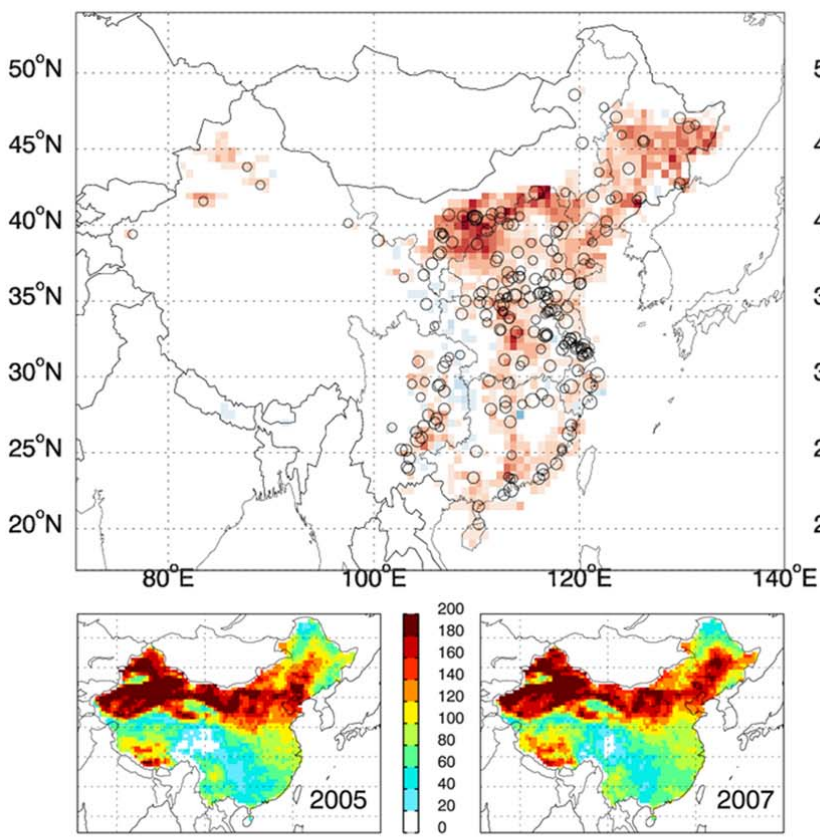

(b) Summer Average
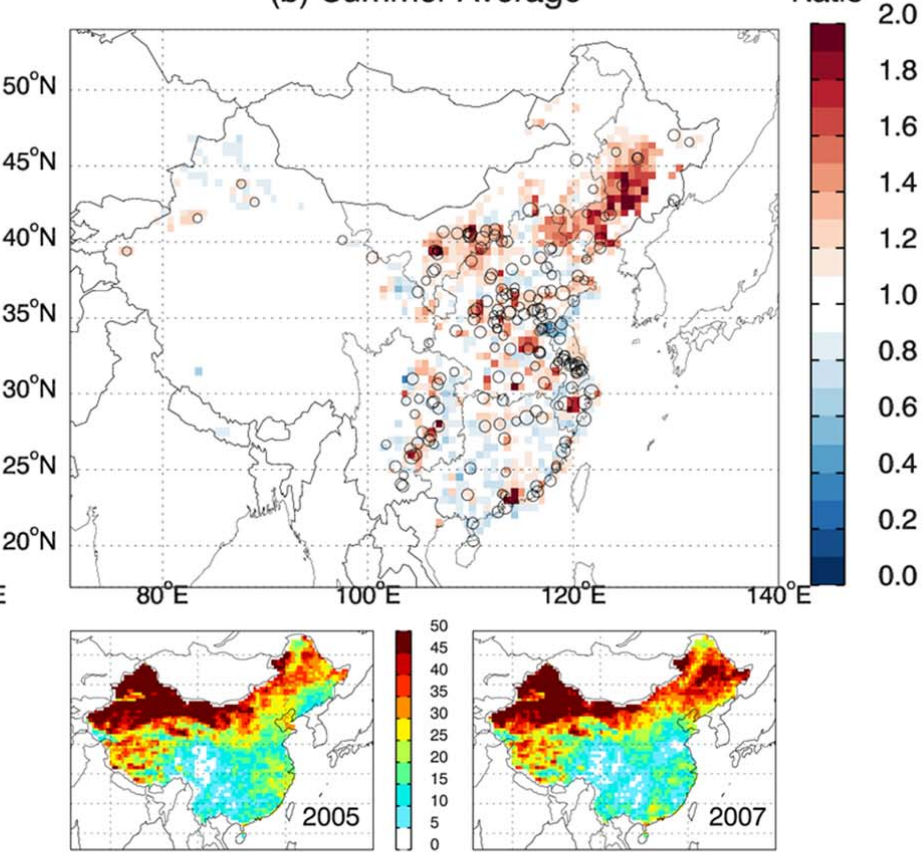

Fig. 7. Ratios of average OMI tropospheric $\mathrm{NO}_{2}$ columns between 2007 and 2005 using (a) annual averages and (b) summer averages. Only grids inside Chinese boundary and with average $\mathrm{NO}_{2}$ columns $>1.0 \times 10^{15}$ molecules $\mathrm{cm}^{-2}$ in both years are colored. Open circles denote the new power plants coming into operation during 2005-2007 (only new power plants coming into operation during June 2005-August 2007 are plotted in (b)), with three sizes from small to large: $<500 \mathrm{MW}, 500-1200 \mathrm{MW},>1200 \mathrm{MW}$. Small maps below each ratio map present the sample amounts used in the averages for the corresponding years (note change of scale).

(a) Annual Average

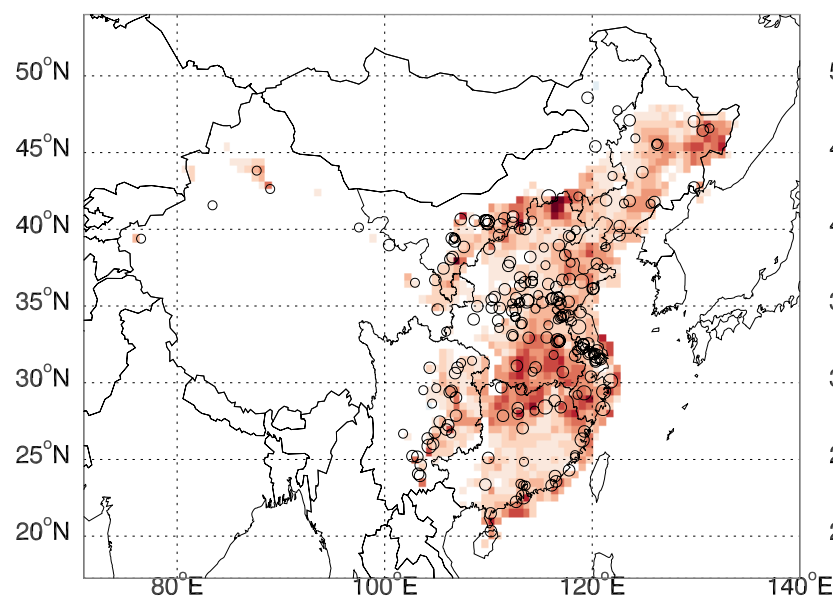

(b) Summer Average

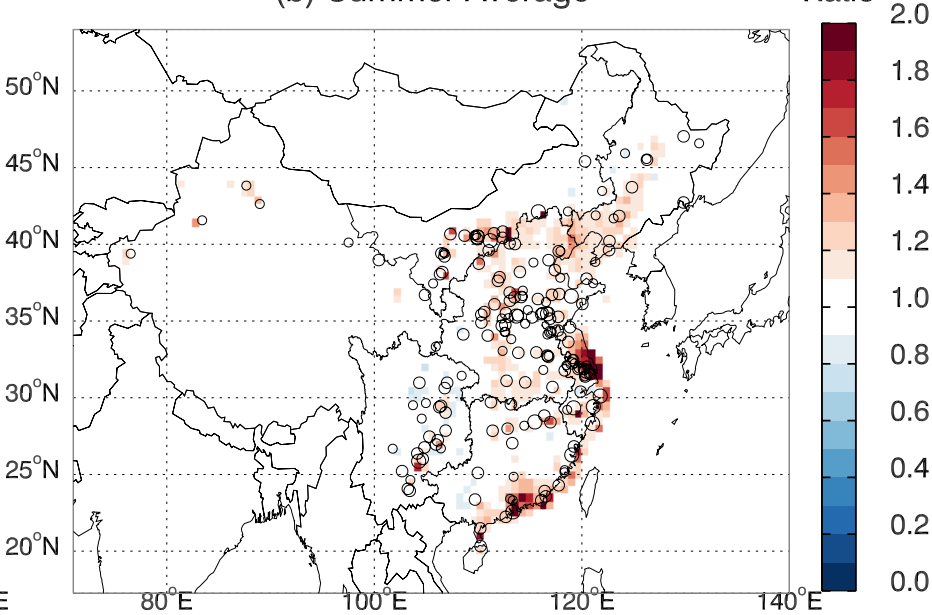

Fig. 8. Ratios of GEOS-Chem modeled tropospheric $\mathrm{NO}_{2}$ columns between 2007 and 2005 using (a) annual averages and (b) summer averages. The cartography is same as Fig. 7.

the construction of new power plants in Fig. 7. North China and Inner Mongolia, as the main coal-manufacturing bases in China, contain a large number of new power plants and show the fastest growth rates of $\mathrm{NO}_{2}$ columns in the entire country. East China and Southwest China also show large increases of $\mathrm{NO}_{2}$ columns. In contrast, however, there are only a few new power plants in inland areas of South China and the $\mathrm{NO}_{2}$ columns have not significantly increased in this region. It is noteworthy that there are significant increases in some grids without new power plants, and this could also be the result of atmospheric transport of $\mathrm{NO}_{\mathrm{x}}$. This is especially clear in the annual ratio map. 


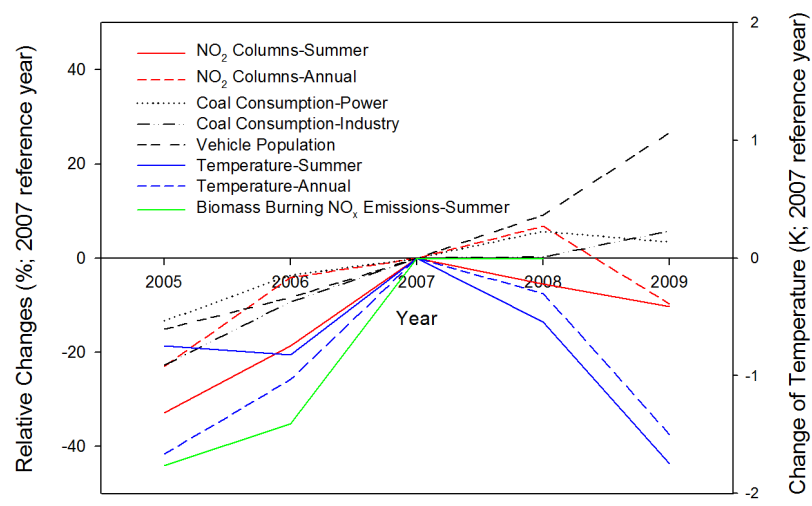

Fig. 9. Relative changes of annual and summer average $\mathrm{OMI} \mathrm{NO}_{2}$ columns, summertime biomass burning $\mathrm{NO}_{\mathrm{x}}$ emissions, and major annual anthropogenic activities, and absolute changes of annual and summer average temperature (2007 as reference year) during 20052009 in Northeast China. Summertime biomass burning emissions were taken from the GFED database (van der Werf et al., 2006).

Figure 8 presents the ratios of annual and summer average tropospheric $\mathrm{NO}_{2}$ columns between 2007 and 2005 from the GEOS-Chem model. The modeled annual and summer ratios show similar spatial distributions as indicated by OMI, with the most significant increases in North China and Inner Mongolia and no significant increase in inland areas of South China. The growth rates of summer average columns in North China from OMI are higher than those from the model and have broader spatial extent, possibly related to some missing newly added industrial sources.

Many new power plant clusters locate in East China, but the ratios of $\mathrm{NO}_{2}$ columns in this region are not as notable as those in North China and Inner Mongolia. This is due to the fact that East China has the most intensive $\mathrm{NO}_{\mathrm{x}}$ emissions in the whole country, and consequently, the observations of power plant emissions could be interfered with by the large contributions of emissions from other source types. There is a chain of new power plants in Sichuan, Chongqing, and Guizhou in Southwest China, visible in both the OMI and model data. But as the sample amounts of OMI measurements are very small (see Fig. 7) in summer in this region, due to the typical rainy weather, the ratios of summer average columns are not as distinct as the ratios of annual average columns in some grids.

The model shows significant increases of summer $\mathrm{NO}_{2}$ columns over the new power plants in coastal regions of South China, while OMI observed decrease trend in summer columns over those locations. The reasons of this discrepancy remain unclear, but it is possible due to the undersampled a priori parameters in a large grid in $\mathrm{NO}_{2}$ retrievals (Heckel et al., 2011), or inaccurate representation of coastal metrological filed in GESO-5 model. In Northeast China, OMI viewed significant increases of summer average $\mathrm{NO}_{2}$ columns during 2005-2007, surpassing the variations of all major anthropogenic indexes (shown in Fig. 9). Natural emissions may contribute to this increase because summer temperature and biomass burning activities in 2007 were the highest among 2005-2009 in Northeast China. However, further investigation is needed to confirm this guess.

In Fig. 10, we present five power plants as examples to show how OMI can identify the temporal evolution of $\mathrm{NO}_{\mathrm{x}}$ emissions over individual power plants with large new generator units. The $\mathrm{NO}_{2}$ columns observed by OMI varied synchronously with the modeled columns, both surging dramatically (decreasing in Fig. 10e) after the new generator units came into operation. The successful identification of the emission evolutions over individual power plants using OMI measurements could be very useful for Ministry of Environmental Protection in China to monitor the current emission status and operations of pollutant control devices in power plants. However, this method greatly depends on the sample amounts and the location of power plants. Averaging and smoothing satellite observations for multi-years could provide more accurate top-down estimates on large point source emissions (Beirle et al., 2011; Fioletov et al., 2011), and we will extend the analysis for a longer period in our future work.

\subsection{Contributions of power plant emissions to $\mathrm{NO}_{2}$ columns}

In order to quantify the contributions of power plant $\mathrm{NO}_{\mathrm{x}}$ emissions to $\mathrm{NO}_{2}$ columns, three scenarios with different power plant $\mathrm{NO}_{\mathrm{x}}$ emissions were examined in the nested-grid GEOS-Chem for the period of 2005-2007: (1), with the complete unit-based power plant emission inventory (hereinafter referred to simply as GC_PP); (2), without power plant emissions (hereinafter called GC_NoPP); and (3), with the unitbased power plant emission inventory for the same period, but without emissions from the generator units that came into operation in 2005-2007 (hereinafter called GC_NoNPP).

Figure 11 shows the relative contributions of the power plants to the annual average $\mathrm{NO}_{2}$ columns in 2005 and 2007, which are defined as the relative differences between GC_PP and GC_NoPP. In Inner Mongolia, central North China and part of Southwest China, power plants contribute to more than $60 \%$ of $\mathrm{NO}_{2}$ columns. The share of power plant pollution was increased in Inner Mongolia and Southwest China during 2005-2007, where power plants dominated the increases of $\mathrm{NO}_{\mathrm{x}}$ emissions over that period. The share of power plant pollution decreased in mega-cities (e.g., Beijing and Guangzhou) as no new power plant was built in megacities and emissions from industries and transportation grew fast.

Figure 12 plots the relative contributions of the new power plants to the annual and summer average $\mathrm{NO}_{2}$ columns in 2007, which are defined as the ratio of the difference between annual (or summer) average $\mathrm{NO}_{2}$ columns in 2007 
(a) P1 (2400MW)

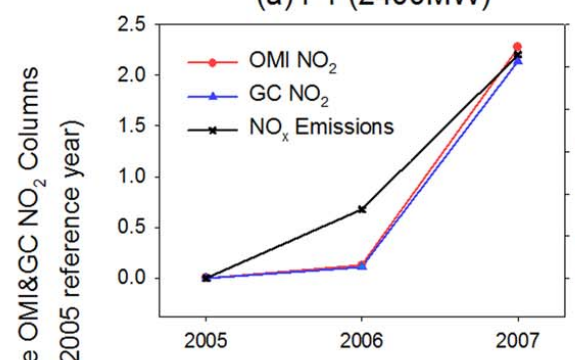

(d) P4 (1200MW) (b) P2 (2400MW)

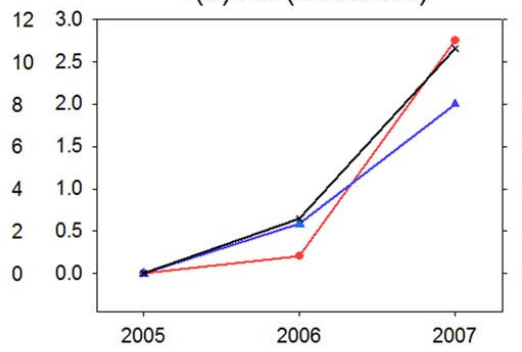

(e) P5 (1200MW)

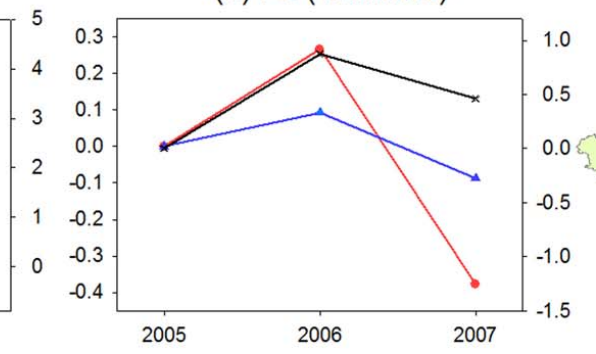

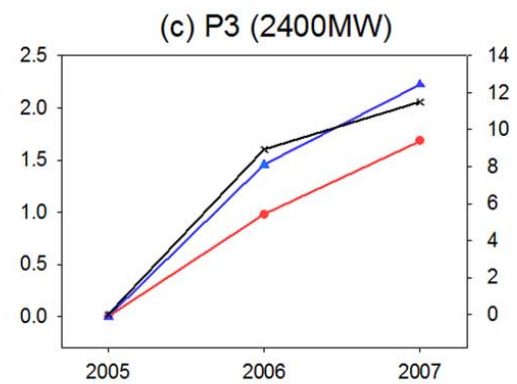

(f) Locations
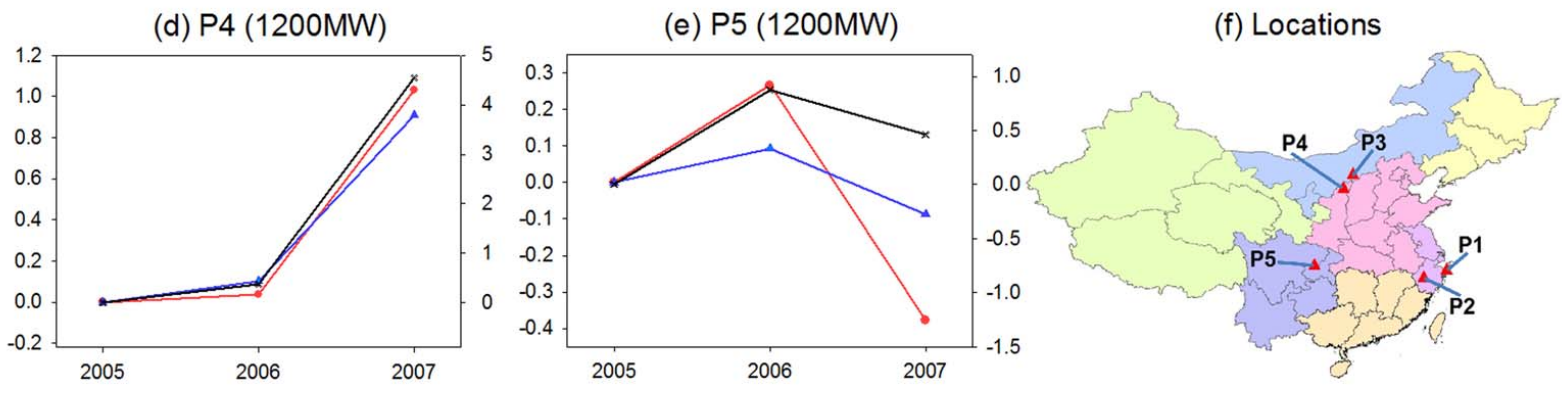

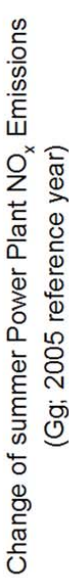

Fig. 10. Changes of summer average OMI and GEOS-Chem tropospheric $\mathrm{NO}_{2}$ columns and power plant $\mathrm{NO}_{\mathrm{x}}$ emissions during 2005-2007 (2005 reference year) over five large new power plants. Numbers in the parentheses in the subtitles denote the new generation capacities added during June 2005-August 2007. Locations of the power plants are indicated in (f).

(a) 2005

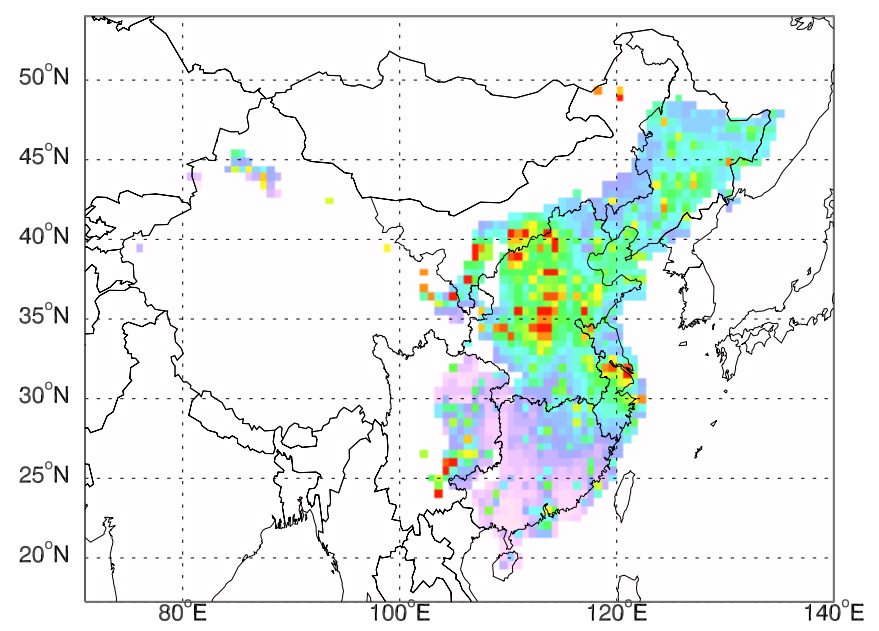

(b) 2007

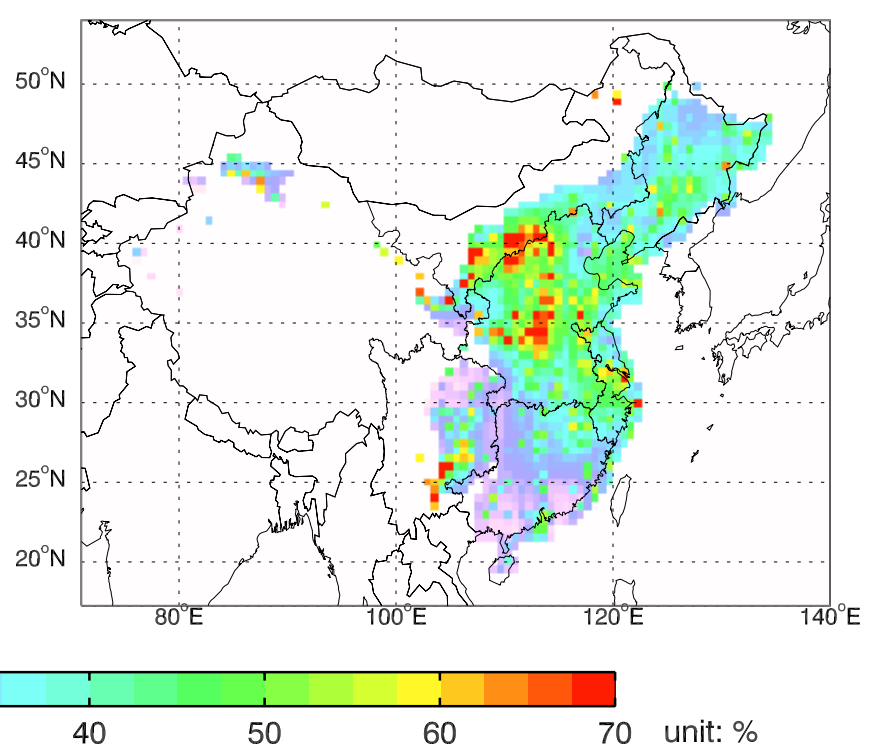

Fig. 11. Relative contributions of the power plant $\mathrm{NO}_{\mathrm{x}}$ emissions to the annual average $\mathrm{NO}_{2}$ columns in (a) 2005 and (b) 2007 , defined as the relative differences between GC_PP and GC_NoPP. Only grids inside Chinese boundary and with average $\mathrm{NO}_{2}$ columns $>1.0 \times 10^{15}$ molecules $\mathrm{cm}^{-2}$ in GC_PP are colored.

from GC_PP and GC_NoNPP to the columns from GC_PP in 2007:

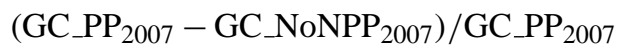

As shown in Fig. 12, the impact of the new power plants are well constrained around the emitters in summer due to the short lifetime of $\mathrm{NO}_{\mathrm{x}}$, but expand over a wider scale in the annual average map as longer $\mathrm{NO}_{\mathrm{x}}$ lifetime in other seasons will allow $\mathrm{NO}_{\mathrm{x}}$ plumes from power plants transport to further distances. This is also consistent with the 
(a) Annual

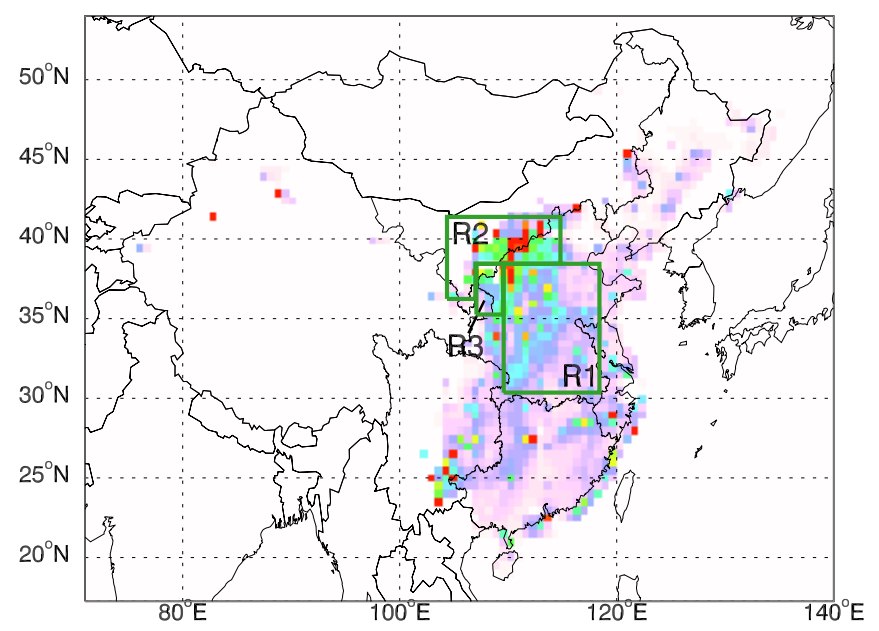

(b) Summer

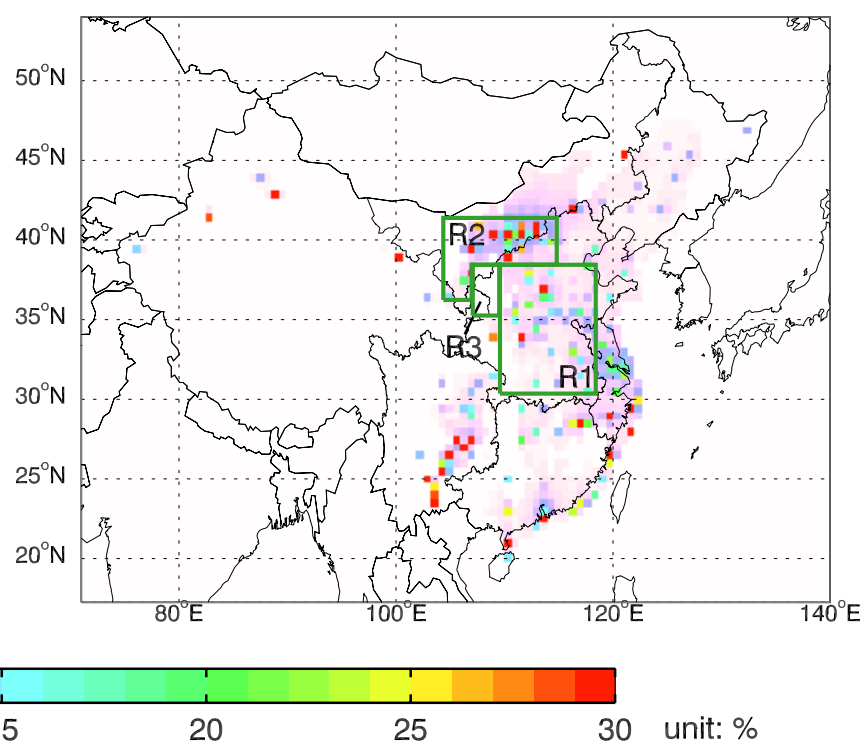

Fig. 12. Relative contributions of the new power plant $\mathrm{NO}_{\mathrm{x}}$ emissions to the (a) annual average $\mathrm{NO}_{2}$ columns and (b) summer average $\mathrm{NO}_{2}$ columns in 2007, defined as Eq. (2). Only grids inside Chinese boundary and with average $\mathrm{NO}_{2}$ columns $>1.0 \times 10^{15}$ molecules $\mathrm{cm}^{-2}$ in GC_PP are colored. Domains of three studied regions are indicated in green rectangles.
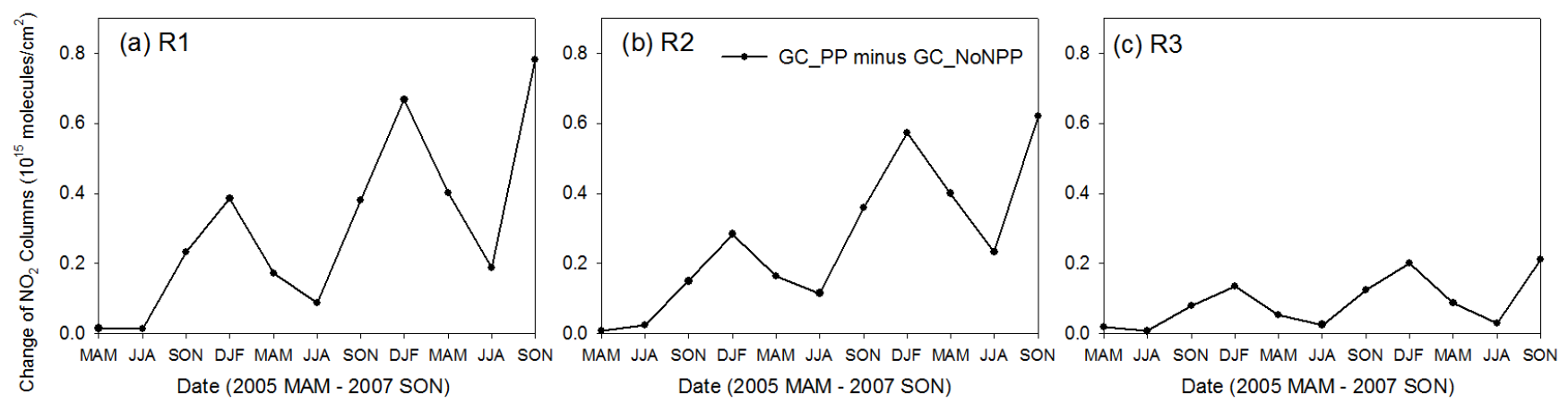

Fig. 13. Seasonal evolution of $\mathrm{NO}_{2}$ columns from the new power plants, defined as the absolute differences between GC_PP and GC_NoNPP, during 2005 MAM to 2007 SON in the three regions in Fig. 12.

satellite observations presented in Fig. 7. In Fig. 12, R1 and $\mathrm{R} 2$ are two major regions with dramatic increases of $\mathrm{NO}_{2}$ columns due to the new power plant emissions, as mentioned in Sect. 5.1; R3 is a background region where there is scarcely any anthropogenic source. New power plants contributed $10 \%$ and $18.5 \%$ to 2007 annual average $\mathrm{NO}_{2}$ columns in R1 and R2, respectively, indicating the large environmental impact of new power plant constructions. New power plants have higher contribution to $\mathrm{NO}_{2}$ columns in $\mathrm{R} 2$ compared to in $\mathrm{R} 1$ because power plant emissions in $\mathrm{R} 2$ are more dominant.

We further examined the evolution of $\mathrm{NO}_{2}$ columns from the new power plants by season in three selected regions, as shown in Fig. 13. In R1 and R2, the increase of $\mathrm{NO}_{2}$ columns due to new power plants shows a clear upward trend with strong seasonal variations, reflecting the gradually increased contribution from new power plants and differences of $\mathrm{NO}_{\mathrm{x}}$ lifetime in four seasons. The contributions of new power plants to $\mathrm{NO}_{2}$ columns in $\mathrm{R} 3$ are very limited in summer, but could be up to $0.21 \times 10^{15}$ molecules $\mathrm{cm}^{-2}$ in winter through transportation.

\section{Impacts of new power plant $\mathrm{NO}_{\mathrm{x}}$ emissions on satellite retrievals}

The OMI tropospheric $\mathrm{NO}_{2}$ column retrievals are sensitive to the changes in the a priori $\mathrm{NO}_{2}$ shape factors used in the calculation of AMF. A new large surface emitter such as a power plant would cause a considerable change in the local $\mathrm{NO}_{2}$ 

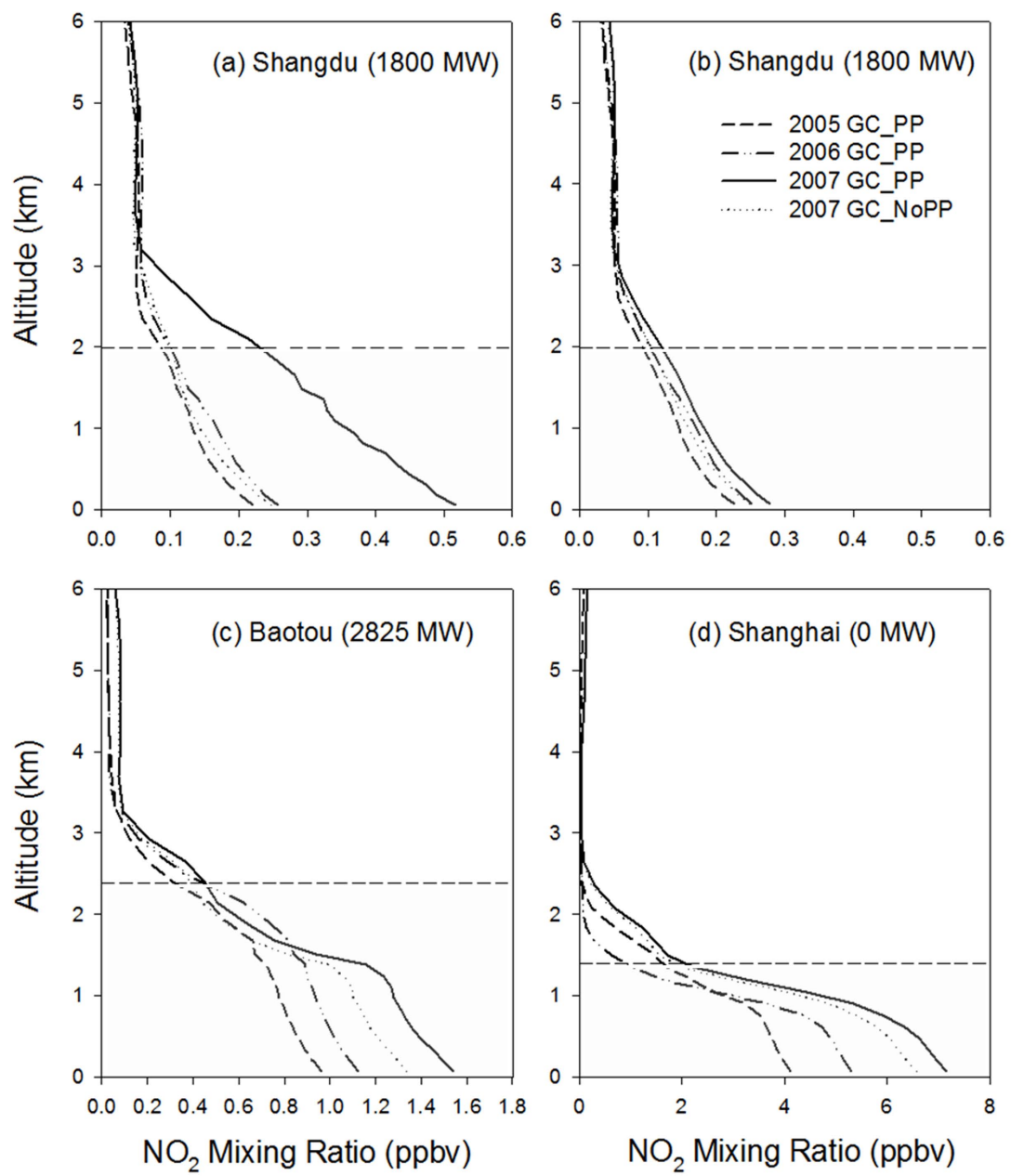

Fig. 14. $\mathrm{NO}_{2}$ profiles from surface to $6 \mathrm{~km}$ for July in $2005-2007$ generated from the nested-grid $\left(0.5^{\circ} \times 0.667^{\circ}\right)$ GEOS-Chem model over Shangdu (a), Baotou (c), and Shanghai (d), and from the $2^{\circ} \times 2.5^{\circ}$ GEOS-Chem model over Shangdu (b). GC_PP denotes the GEOSChem simulations with all unit-based power plant emissions, and GC_NoNPP denotes the GEOS-Chem simulations without new power plant emissions. Dash lines indicate the average PBL heights. Numbers in the parentheses in the subtitles denote the new generation capacities added during June 2005-August 2007.

Table 4. Summer average $\mathrm{OMI} \mathrm{NO}_{2}$ columns derived with different a priori $\mathrm{NO}_{2}$ profiles over various sites ${ }^{\mathrm{a}}$.

\begin{tabular}{|c|c|c|c|c|c|c|c|c|}
\hline \multirow[t]{2}{*}{ Site } & \multirow[t]{2}{*}{ Location } & \multirow[t]{2}{*}{ Category } & \multirow[t]{2}{*}{$\begin{array}{l}\text { New Capacity } \\
\text { (MW) }\end{array}$} & \multicolumn{3}{|c|}{$\begin{array}{l}\mathrm{NO}_{2} \text { Columns with } 0.5^{\circ} \times 0.667^{\circ} \text { profiles } \\
\left(10^{15} \text { molecules } \mathrm{cm}^{-2}\right)\end{array}$} & \multicolumn{2}{|c|}{$\begin{array}{l}\mathrm{NO}_{2} \text { Columns with } 2^{\circ} \times 2.5^{\circ} \text { profiles } \\
\left(10^{15} \text { molecules } \mathrm{cm}^{-2}\right)\end{array}$} \\
\hline & & & & 2005 GC_PP & 2007 GC_PP & 2007 GC_NoNPP & 2005 GC_PP & 2007 GC_PP \\
\hline Shangdu & $42.3^{\circ} \mathrm{N}, 116.0^{\circ} \mathrm{E}$ & Rural & 1800 & 1.25 & $2.00(1.60)$ & $1.79(1.44)$ & 1.15 & $1.66(1.45)$ \\
\hline Lingwu & $38.1^{\circ} \mathrm{N}, 106.5^{\circ} \mathrm{E}$ & Rural & 1260 & 2.00 & $2.21(1.11)$ & $2.01(1.01)$ & 1.63 & $1.81(1.11)$ \\
\hline Lanxi & $29.2^{\circ} \mathrm{N}, 119.5^{\circ} \mathrm{E}$ & Town & 2400 & 2.69 & $5.44(2.02)$ & $4.64(1.72)$ & 2.68 & 4.89 (1.82) \\
\hline Tuoketuo & $40.3^{\circ} \mathrm{N}, 111.3^{\circ} \mathrm{E}$ & Town & 2400 & 4.70 & $6.38(1.36)$ & $6.03(1.28)$ & 3.75 & $5.09(1.36)$ \\
\hline Baotou & $40.7^{\circ} \mathrm{N}, 109.7^{\circ} \mathrm{E}$ & Urban & 2825 & 5.14 & $8.39(1.63)$ & $7.96(1.55)$ & 3.63 & $5.69(1.57)$ \\
\hline Wuhai & $39.5^{\circ} \mathrm{N}, 106.2^{\circ} \mathrm{E}$ & Urban & 860 & 4.03 & $8.30(2.06)$ & $8.00(1.99)$ & 2.80 & $5.46(1.95)$ \\
\hline Shanghai & $31.2^{\circ} \mathrm{N}, 121.5^{\circ} \mathrm{E}$ & Metropolis & 0 & 12.48 & $11.64(0.93)$ & $11.54(0.92)$ & 10.78 & $9.76(0.91)$ \\
\hline Beijing & $39.9^{\circ} \mathrm{N}, 116.4^{\circ} \mathrm{E}$ & Metropolis & 0 & 7.50 & $10.52(1.40)$ & $10.53(1.40)$ & 6.49 & $9.05^{\circ}(1.39)$ \\
\hline
\end{tabular}

${ }^{a}$ Values in the parenthesis indicate the ratios of $\mathrm{NO}_{2}$ columns in 2007 to the corresponding $\mathrm{NO}_{2}$ columns in 2005.

${ }^{\mathrm{b}}$ Capacities of new generator units which came into operation in June 2005-August 2007. 
shape factor. However, this potential impact has not been explicitly considered yet in the operational space-borne products, because $\mathrm{NO}_{2}$ shape factors are usually generated by a CTM driven by fixed emissions for all years.

We choose three representative cases to demonstrate the impacts of the new power plant $\mathrm{NO}_{\mathrm{x}}$ emissions on $\mathrm{NO}_{2}$ profiles in Fig. 14: new power plants in rural area (Shangdu), new power plants in urban area (Baotou), and no new power plant in urban area (Shanghai). July-average $\mathrm{NO}_{2}$ profiles from the nested-grid GEOS-Chem model for these three sites are presented in Fig. 14a, c, d, three from GC_PP for 20052007 and one from GC_NoNPP for 2007. To understand the impacts of new power plant emissions on $\mathrm{NO}_{2}$ profiles at a coarser resolution, which are typically used in the operational satellite products, we conducted the $2^{\circ} \times 2.5^{\circ}$ GEOSChem simulations for 2005-2007 with the same emission inputs used in the nested-grid GEOS-Chem model. Four Julyaverage $\mathrm{NO}_{2}$ profiles from the $2^{\circ} \times 2.5^{\circ}$ GEOS-Chem model for Shangdu are presented in Fig. 14b. In Fig. 14a, the $\mathrm{NO}_{2}$ concentrations in the lower atmosphere in Shangdu dramatically increased in 2007 due to the new power plant emissions added at the end of 2006. The differences between $\mathrm{NO}_{2}$ profiles at $0.5^{\circ} \times 0.667^{\circ}$ resolution from GC_PP and GC_NoNPP for 2007 are very significant up to $3 \mathrm{~km}$ in altitude, far above the PBL. In contrast, only minimal increases of $\mathrm{NO}_{2}$ are found between the two profiles for 2007 in Fig. 14b, indicating that the impacts of new power plants on $\mathrm{NO}_{2}$ profiles at the $2^{\circ} \times 2.5^{\circ}$ resolution are not significant. In Baotou, an industrial city in Inner Mongolia, the surface $\mathrm{NO}_{2}$ concentrations increased gradually in 2005-2007 along with the continuously added $\mathrm{NO}_{\mathrm{x}}$ emissions from both power plants and other anthropogenic sources. In Shanghai, the differences between $\mathrm{NO}_{2}$ profiles from GC_PP and GC_NoNPP for 2007 are very small, while increases of $\mathrm{NO}_{\mathrm{x}}$ from other anthropogenic emissions contribute significantly to the changes of $\mathrm{NO}_{2}$ profiles during 2005-2007.

Since the satellite is less sensitive to $\mathrm{NO}_{2}$ in the lower atmosphere, the increase of surface $\mathrm{NO}_{2}$ concentrations decreases the local AMF, and thus the retrieved tropospheric $\mathrm{NO}_{2}$ columns would be underestimated in the grids with new power plants if no correction were conducted to the $\mathrm{NO}_{2}$ shape factors. We compare summer average OMI $\mathrm{NO}_{2}$ columns derived with different a priori $\mathrm{NO}_{2}$ profiles over eight sites in Table 4. The $\mathrm{NO}_{2}$ columns in summer 2007 calculated using GC_PP $\mathrm{NO}_{2}$ profiles are $3.8-17.2 \%$ higher than those calculated using GC_NoNPP $\mathrm{NO}_{2}$ profiles over sites with new power plants, more significantly in rural areas and small towns. The simulation data at the nested-grid resolution $\left(0.5^{\circ} \times 0.667^{\circ}\right)$ used in this study could also improve the expression of the effects of new power plant emissions on the $\mathrm{NO}_{2}$ profiles. The sensitivity analysis compared to OMI retrievals with $\mathrm{NO}_{2}$ profiles generated from the global GEOS-Chem simulation $\left(2^{\circ} \times 2.5^{\circ}\right)$ suggests that the use of $\mathrm{NO}_{2}$ profiles at $0.5^{\circ} \times 0.667^{\circ}$ resolution could produce more significant growth rates over grids with new power plants (see Table 4). In sites isolated from the populous regions, e.g., Shangdu and Lanxi, the effects from the resolution of the a priori $\mathrm{NO}_{2}$ profiles used in the $\mathrm{NO}_{2}$ retrievals can be up to $20 \%$, which obviously cannot be ignored in any trend analysis or quantification study.

It should be noted that the sensitivity analysis discussed here is subject to uncertainty. The fresh power plant plumes would not be laterally mixed within a $0.5^{\circ} \times 0.667^{\circ}$ grid. Vertical distribution of emissions could vary within one model grid as functions of wind speed and downstream distances (Weil et al., 2004). Chemical transport model with finer horizontal resolutions and observation measurements should be used in future studies to reduce this uncertainty. Other parameters such as the aerosol profiles could also be affected by the new power plant emissions $\left(\mathrm{SO}_{2}\right.$ and $\left.\mathrm{NO}_{\mathrm{x}}\right)$ and cause some biases in the satellite retrievals. The scattering sulfate aerosols could increase the satellite's sensitivity to the $\mathrm{NO}_{2}$ mixing in and above the aerosol layers (Leitão et al., 2010). However, there is no explicit correction for aerosol changes in the OMI product used in this work.

\section{Concluding remarks}

In this paper, we have demonstrated the rapid growth of power plant $\mathrm{NO}_{\mathrm{x}}$ emissions in 2005-2007 and their contributions to the increasing $\mathrm{NO}_{2}$ columns in China, based on a unit-based power plant $\mathrm{NO}_{\mathrm{x}}$ emission inventory for mainland China, nested-grid GEOS-Chem model, and OMI observations. This inventory was based on a Chinese power plant database, and was validated through comparing the GEOSChem modeled $\mathrm{NO}_{2}$ columns with OMI measurements in summers 2005 and 2007 over grids dominated by power plant $\mathrm{NO}_{\mathrm{x}}$ emissions. The major conclusions and implications can be drawn as follows.

The annual $\mathrm{NO}_{\mathrm{x}}$ emissions from coal-fired power plants were estimated to be $8.11 \mathrm{Tg}$, for 2005 and $9.58 \mathrm{Tg}$ for 2007 , respectively. The rapid growth of the power plant $\mathrm{NO}_{\mathrm{x}}$ emissions was mainly due to the $161.4 \mathrm{GW}$ of new generator units constructed in the period of 2005-2007, which led to a $48.8 \%$ increase of the coal-fired power generation capacity during this period. Generator units with size $\geq 300 \mathrm{MW}$ accounted for $92.2 \%$ of the total capacity additions. It is worth emphasizing that the structural readjustment in the power sector aimed at energy conservation and emission reduction is still in rapid progress and will have positive effects on the $\mathrm{NO}_{\mathrm{x}}$ emissions in China in the future.

The unit-based power plant $\mathrm{NO}_{\mathrm{x}}$ emissions were validated using the improved $\mathrm{OMI} \mathrm{NO}_{2}$ retrievals and the nested-grid GEOS-Chem model. The OMI-derived and GEOS-Chemmodeled summer average tropospheric $\mathrm{NO}_{2}$ columns for 2005 and 2007 were well correlated $\left(R^{2}=0.79-0.82\right)$ over grids dominated by power plant $\mathrm{NO}_{\mathrm{x}}$ emissions, with 7$14 \%$ low bias in modeled $\mathrm{NO}_{2}$ columns. This bias was within the uncertainty range of the power plant emission 
estimates, lending support to the high accuracy of the unitbased power plant $\mathrm{NO}_{\mathrm{x}}$ emission inventory. The comparisons involving more grids produced more scatter over grids with elevated $\mathrm{NO}_{2}$ concentrations, indicating that $\mathrm{NO}_{\mathrm{x}}$ emissions were relatively poorly understood over the regions where power plant emissions were mixed with other anthropogenic sources. This validated power plant inventory also facilitates forward investigations of the emissions in other anthropogenic sources by separating the power plant emissions out.

OMI observed dramatic increases of $\mathrm{NO}_{2}$ columns during 2005-2007 in China attributed to the construction of new power plants. North China and Inner Mongolia showed the fastest growth rates of $\mathrm{NO}_{2}$ columns in the country, followed by East China. Infrequent sampling in the Sichuan Basin and South China made it difficult to capture the signals of some new power plants in summer. The coarse-resolution a priori $\mathrm{NO}_{2}$ shape factors used in the satellite retrievals also reduced the accuracy of $\mathrm{NO}_{2}$ columns near the coastline, introducing an additional bias in the observations of new power plants there. We found that OMI had the capability to trace the changes of $\mathrm{NO}_{\mathrm{x}}$ emissions over individual power plants, e.g., the addition of new generator units, in the cases where there was less interference from other $\mathrm{NO}_{\mathrm{x}}$ sources. This application can be used to provide useful information to the environmental officials to monitor the emissions and evaluate the possible reductions due to the application of control devices in power plants in the future.

Sensitivity analysis with two scenarios of GEOS-Chem simulations, with and without new power plant emissions, suggested that the relative contributions of these new power plants to the annual average $\mathrm{NO}_{2}$ columns in 2007 were $10 \%$ in North China and $18.5 \%$ in Inner Mongolia. The contribution of new power plants to $\mathrm{NO}_{2}$ columns in North China showed a clear upward trend with strong seasonal variations, reflecting the gradually increased contribution from new power plants and differences of $\mathrm{NO}_{\mathrm{x}}$ lifetime in four seasons.

The new power plant $\mathrm{NO}_{\mathrm{x}}$ emissions can have a significant impact on the satellite retrieval by changing the $\mathrm{NO}_{2}$ shape factor. The effects from new power plant emissions caused 3.8-17.2\% increases in the summer average OMI tropospheric $\mathrm{NO}_{2}$ columns for the six selected sites, more significantly in rural areas and small towns. The fine-resolution data used in this study improved the expression of the effects of new power plant emissions on the $\mathrm{NO}_{2}$ profiles, especially in areas isolated from the populous regions, resulted in up to $20 \%$ increases of the summer average $\mathrm{NO}_{2}$ column ratios between 2007 and 2005 compared to OMI retrievals with $\mathrm{NO}_{2}$ profiles generated from a global GEOS-Chem simulation $\left(2^{\circ} \times 2.5^{\circ}\right)$. It is worth considering the use of a priori shape factors generated by a CTM with temporally varying bottom-up emissions and at a reasonably high resolution in the operational satellite retrieval products. The changes of aerosols and plume chemistry over the new power plants should also be further investigated in the future.
Acknowledgements. The work is funded by China's National Basic Research Program (2010CB951803), the National Natural Science Foundation of China (20921140409) and the Ministry of Environmental Protection of China (200909002). Siwen Wang acknowledges the support of the Joint-Training Program organized by the China Scholarship Council. We acknowledge the free use of tropospheric $\mathrm{NO}_{2}$ column data from the OMI sensor from www.temis.nl. We would also like to thank two anonymous referees for their valuable comments on this work. This study is a contribution to the NASA Air Quality Applied Sciences Team (AQAST) for emissions evaluation and improvement using advanced Earth System tools, hosted at Argonne National Laboratory.

Edited by: I. Aben

\section{References}

Baughcum, S. L., Tritz, T. G., Henderson, S. C., and Pickett, D. C.: Scheduled civil aircraft emission inventories for 1992: database development and analysis, NASA CR-4700, NASA, Washington DC, USA, 1996.

Beirle, S., Boersma, K. F., Platt, U., Lawrence, M. G., and Wagner, T.: Megacity emissions and lifetimes of nitrogen oxides probed from space, Science, 333, 1737-1739, 2011.

Bey, I., Jacob, D. J., Yantosca, R. M., Logan, J. A., Field, B. D., Fiore, A. M., Li, Q. B., Liu, H. Y., Mickley, L. J., and Schultz, M. G.: Global modeling of tropospheric chemistry with assimilated meteorology: Model description and evaluation, J. Geophys. Res., 106, 23073-23095, doi:10.1029/2001JD000807, 2001.

Bhaduri, B., Bright, E., Coleman, P., and Dobson, J.: LandScan: locating people is what matters, Geoinfomatics, 5, 34-37, 2002.

Boersma, K. F., Bucsela, E., Brinksma, E., and Gleason, J. F.: $\mathrm{NO}_{2}$, in: OMI Algorithm Theoretical Basis Document, vol. IV, Trace Gas Algorithms, edited by: Chance, K., NASA Goddard Space Flight Cent., Greenbelt, Md, 15-36, 2002.

Boersma, K. F., Eskes, H. J., and Brinksma, E. J.: Error analysis for tropospheric $\mathrm{NO}_{2}$ retrieval from space, J. Geophys. Res., 109, D04311, doi:10.1029/2003JD003962, 2004.

Boersma, K. F., Eskes, H. J., Veefkind, J. P., Brinksma, E. J., van $\operatorname{der}$ A, R. J., Sneep, M., van den Oord, G. H. J., Levelt, P. F., Stammes, P., Gleason, J. F., and Bucsela, E. J.: Near-real time retrieval of tropospheric $\mathrm{NO}_{2}$ from OMI, Atmos. Chem. Phys., 7, 2103-2118, doi:10.5194/acp-7-2103-2007, 2007.

Boersma, K. F., Eskes, H. J., Dirksen, R. J., van der A, R. J., Veefkind, J. P., Stammes, P., Huijnen, V., Kleipool, Q. L., Sneep, M., Claas, J., Leitão, J., Richter, A., Zhou, Y., and Brunner, D.: An improved tropospheric $\mathrm{NO}_{2}$ column retrieval algorithm for the Ozone Monitoring Instrument, Atmos. Meas. Tech., 4, 1905-1928, doi:10.5194/amt-4-1905-2011, 2011.

Bovensmann, H., Burrows, J. P., Buchwitz, M., Frerick, J., Nö̈l, S., Rozanov, V. V., Chance, K. V., and Goede, A. P. H.: SCIAMACHY: Mission objectives and measurement modes, J. Atmos. Sci., 56, 127-150, 1999.

Bucsela, E. J., Celarier, E. A., Wenig, M. O., Gleason, J. F., Veefkind, J. P., Boersma, K. F., and Brinksma, E. J.: Algorithm for $\mathrm{NO}_{2}$ vertical column retrieval from the Ozone Monitoring 
Instrument, IEEE T. Geosci. Remote Sens., 44, 1245-1258, doi:10.1109/TGRS.2005.863715, 2006.

Carn, S. A., Krueger, A. J., Krotkov, N. A., Yang, K., and Levelt, P. F.: Sulfur dioxide emissions from Peruvian copper smelters detected by the Ozone Monitoring Instrument, Geophys. Res. Lett., 34, L09801, doi:10.1029/2006GL029020, 2007.

Celarier, E. A., Brinksma, E. J., Gleason, J. F., Veefkind, J. P., Cede, A., Herman, J. R., Ionov, D., Goutail, F., Pommereau, J.P., Lambert, J.-C., van Roozendael, M., Pinardi, G., Wittrock, F., Schönhardt, A., Richter, A., Ibrahim, O. W., Wagner, T., Bojkov, B., Mount, G., Spinei, E., Chen, C. M., Pongetti, T. J., Sander, S. P., Bucsela, E. J., Wenig, M. O., Swart, D. P. J., Volten, H., Kroon, M., and Levelt, P. F.: Validation of ozone monitoring instrument nitrogen dioxide columns, J. Geophys. Res., 113, D15S15, doi:10.1029/2007JD008908, 2008.

Chen, D., Wang, Y., McElroy, M. B., He, K., Yantosca, R. M., and Le Sager, P.: Regional CO pollution and export in China simulated by the high-resolution nested-grid GEOS-Chem model, Atmos. Chem. Phys., 9, 3825-3839, doi:10.5194/acp-9-3825-2009, 2009.

Clarke, M. R. B.: The reduced major axis of a bivariate sample, Biometrika, 67, 441-446, doi:10.1093/biomet/67.2.441, 1980.

Dirksen, R. J., Boersma, K. F., Eskes, H. J., Ionov, D. V., Bucsela, E. J., Levelt, P. F., and Kelder, H. M.: Evaluation of stratospheric $\mathrm{NO}_{2}$ retrieved from the Ozone Monitoring Instrument: intercomparison, diurnal cycle and trending, J. Geophys. Res., 116, D08305, doi:10.1029/2010JD014943, 2011.

Eskes, H. J. and Boersma, K. F.: Averaging kernels for DOAS totalcolumn satellite retrievals, Atmos. Chem. Phys., 3, 1285-1291, doi:10.5194/acp-3-1285-2003, 2003.

Fioletov, V. E., McLinden, C. A., Krotkov, N., Moran, M. D., and Yang, K.: Estimation of $\mathrm{SO}_{2}$ emissions using OMI retrievals, Geophys. Res. Lett., 38, L21811, doi:10.1029/2011GL049402, 2011.

Ghude, S. D., Fadnavis, S., Beig, G., Polade, S. D., and van der A, R. J.: Detection of surface emission hot spots, trends, and seasonal cycle from satellite-retrieved $\mathrm{NO}_{2}$ over India, J. Geophys. Res., 113, D20305, doi:10.1029/2007JD009615, 2008.

Hains, J. C., Boersma, K. F., Kroon, M., Dirksen, R. J., Cohen, R. C., Perring, A. E., Bucsela, E., Volten, H., Swart, D. P. J., Richter, A., Wittrock, F., Schoenhardt, A., Wagner, T., Ibrahim, O. W., van Roozendael, M., Pinardi, G., Gleason, J. F., Veefkind, J. P., and Levelt, P.: Testing and improving OMI DOMINO tropospheric $\mathrm{NO}_{2}$ using observations from the DANDELIONS and INTEX-B validation campaigns, J. Geophys. Res., 115, D05301, doi:10.1029/2009JD012399, 2010.

Hao, J. M., Tian, H. Z., and Lu, Y. Q.: Emission inventories of $\mathrm{NO}_{\mathrm{x}}$ from commercial energy consumption in China, 1995-1998, Environ. Sci. Technol., 36, 552-560, 2002.

Heckel, A., Kim, S.-W., Frost, G. J., Richter, A., Trainer, M., and Burrows, J. P.: Influence of low spatial resolution a priori data on tropospheric $\mathrm{NO}_{2}$ satellite retrievals, Atmos. Meas. Tech., 4, 1805-1820, doi:10.5194/amt-4-1805-2011, 2011.

Jaeglé, L., Steinberger, L., Martin, R. V., and Chance, K.: Global partitioning of $\mathrm{NO}_{\mathrm{x}}$ sources using satellite observations: Relative roles of fossil fuel combustion, biomass burning and soil emissions, Faraday Discus., 130, 407-423, doi:10.1039/b502128f, 2005.
Kim, S.-W., Heckel, A., McKeen, S. A., Frost, G. J., Hsie, E.-Y., Trainer, M. K., Richter, A., Burrows, J. P., Peckham, S. E., and Grell, G. A.: Satellite-observed U.S. power plant $\mathrm{NO}_{\mathrm{x}}$ emission reductions and their impact on air quality, Geophys. Res. Lett., 33, L22812, doi:10.1029/2006GL027749, 2006.

Kim, S.-W., Heckel, A., Frost, G. J., Richter, A., Gleason, J., Burrows, J. P., McKeen, S., Hsie, E.-Y., Granier, C., and Trainer, M.: $\mathrm{NO}_{2}$ columns in the western United States observed from space and simulated by a regional chemistry model and their implications for $\mathrm{NO}_{\mathrm{x}}$ emissions, J. Geophys. Res., 114, D11301, doi:10.1029/2008JD011343, 2009.

Konovalov, I. B., Beekmann, M., Richter, A., and Burrows, J. P.: Inverse modelling of the spatial distribution of $\mathrm{NO}_{\mathrm{X}}$ emissions on a continental scale using satellite data, Atmos. Chem. Phys., 6, 1747-1770, doi:10.5194/acp-6-1747-2006, 2006.

Lamsal, L. N., Martin, R. V., van Donkelaar, A., Celarier, E. A., Bucsela, E. J., Boersma, K. F., Dirksen, R., Luo, C., and Wang, Y.: Indirect validation of tropospheric nitrogen dioxide retrieved from the OMI satellite instrument: Insight into the seasonal variation of nitrogen oxides at northern midlatitudes, J. Geophys. Res., 115, D05302, doi:10.1029/2009JD013351, 2010.

Lamsal, L. N., Martin, R. V., Padmanabhan, A., van Donkelaar, A., Zhang, Q., Sioris, C. E., Chance, K., Kurosu, T. P., and Newchurch, M. J.: Application of satellite observations for timely updates to global anthropogenic $\mathrm{NO}_{\mathrm{x}}$ emission inventories, Geophys. Res. Lett., 38, L05810, doi:10.1029/2010GL046476, 2011.

Leitão, J., Richter, A., Vrekoussis, M., Kokhanovsky, A., Zhang, Q. J., Beekmann, M., and Burrows, J. P.: On the improvement of $\mathrm{NO}_{2}$ satellite retrievals - aerosol impact on the airmass factors, Atmos. Meas. Tech., 3, 475-493, doi:10.5194/amt-3-475-2010, 2010.

Levelt, P. F., van den Oord, G. H. J., Dobber, M. R., Mälkki, A., Visser, H., de Vries, J., Stammes, P., Lundell, J. O. V., and Saari, H.: The Ozone Monitoring Instrument, IEEE T. Geosci. Remote Sens., 44, 1093-1101, doi:10.1109/TGRS.2006.872333, 2006.

Li, C., Zhang, Q., Krotkov, N. A., Streets, D. G., He, K. B., Tsay, S.-C., and Gleason, J. F.: Recent large reduction in sulfur dioxide emissions from Chinese power plants observed by the Ozone Monitoring Instrument, Geophys. Res. Lett., 37, L08807, doi:10.1029/2010GL042594, 2010.

Lin, J.-T.: Satellite constraint for emissions of nitrogen oxides from anthropogenic, lightning and soil sources over East China on a high-resolution grid, Atmos. Chem. Phys., 12, 2881-2898, doi:10.5194/acp-12-2881-2012, 2012.

Lin, J.-T. and McElroy, M. B.: Detection from space of a reduction in anthropogenic emissions of nitrogen oxides during the Chinese economic downturn, Atmos. Chem. Phys., 11, 8171-8188, doi:10.5194/acp-11-8171-2011, 2011.

Lin, J. T., McElroy, M. B., and Boersma, K. F.: Constraint of anthropogenic $\mathrm{NO}_{\mathrm{x}}$ emissions in China from different sectors: a new methodology using multiple satellite retrievals, Atmos. Chem. Phys., 10, 63-78, doi:10.5194/acp-10-63-2010, 2010.

Martin, R. V., Jacob, D. J., Chance, K., Kurosu, T. P., Palmer, P. I., and Evans, M. J.: Global inventory of nitrogen oxide emissions constrained by space-based observations of $\mathrm{NO}_{2}$ columns, J. Geophys. Res., 108, 4537, doi:10.1029/2003JD003453, 2003. 
Martin, R. V., Sioris, C. E., Chance, K., Ryerson, T. B., Bertram, T. H., Wooldridge, P. J., Cohen, R. C., Andy Neuman, J., Swanson, A., and Flocke, F. M.: Evaluation of space-based constraints on global nitrogen oxide emissions with regional aircraft measurements over and downwind of eastern North America, J. Geophys. Res., 111, D15308, doi:10.1029/2005JD006680, 2006.

Ohara, T., Akimoto, H., Kurokawa, J., Horii, N., Yamaji, K., Yan, X., and Hayasaka, T.: An Asian emission inventory of anthropogenic emission sources for the period 1980-2020, Atmos. Chem. Phys., 7, 4419-4444, doi:10.5194/acp-7-4419-2007, 2007.

Olivier, J. G. J. and Berdowski, J. J. M.: Global emissions sources and sinks, in: The Climate System, Lisse, The Netherlands, 3378, 2001.

Palmer, P. I., Jacob, D. J., Chance, K., Martin, R. V., Spurr, R. J. D., Kurosu, T. P., Bey, I., Yantosca, R., Fiore, A., and Li, Q. B.: Air mass factor formulation for spectroscopic measurements from satellites: Application to formaldehyde retrievals from the Global Ozone Monitoring Experiment, J. Geophys. Res., 106, 14539-14550, doi:10.1029/2000JD900772, 2001.

Platt, U.: Differential Optical Absorption Spectroscopy (DOAS), in: Air Monitoring by Spectroscopic Techniques, John Wiley, New York, USA, 27-84, 1994.

Richter, A., Burrows, J. P., Nüß, H., Granier, C., and Niemeier, U.: Increase in tropospheric nitrogen dioxide over China observed from space, Nature, 437, 129-132, 2005.

Sauvage, B., Martin, R. V., van Donkelaar, A., and Ziemke, J. R.: Quantification of the factors controlling tropical tropospheric ozone and the South Atlantic maximum, J. Geophys. Res., 112, D11309, doi:10.1029/2006JD008008, 2007.

Schaub, D., Brunner, D., Boersma, K. F., Keller, J., Folini, D., Buchmann, B., Berresheim, H., and Staehelin, J.: SCIAMACHY tropospheric $\mathrm{NO}_{2}$ over Switzerland: estimates of $\mathrm{NO}_{\mathrm{X}}$ lifetimes and impact of the complex Alpine topography on the retrieval, Atmos. Chem. Phys., 7, 5971-5987, doi:10.5194/acp-7-5971-2007, 2007.

Schneider, A., Friedl, M. A., and Potere, D.: A new map of global urban extent from MODIS satellite data, Environ. Res. Lett., 4, 044003, doi:10.1088/1748-9326/4/4/044003, 2009.

Streets, D. G., Bond, T. C., Carmichael, G. R., Fernandes, S. D., Fu, Q., He, D., Klimont, Z., Nelson, S. M., Tsai, N. Y., Wang, M. Q., Woo, J.-H., and Yarber, K. F.: An inventory of gaseous and primary aerosol emissions in Asia in the year 2000, J. Geophys. Res., 108, 8809, doi:10.1029/2002JD003093, 2003.

Tian, H.: Studies on Present and Future Emissions of Nitrogen Oxides and Its Comprehensive Control Policies in China, Ph. D. thesis, Tsinghua Univ., Beijing, 2003.

Valin, L. C., Russell, A. R., Hudman, R. C., and Cohen, R. C.: Effects of model resolution on the interpretation of satellite $\mathrm{NO}_{2}$ observations, Atmos. Chem. Phys., 11, 11647-11655, doi:10.5194/acp-11-11647-2011, 2011.

van der A, R. J., Eskes, H. J., Boersma, K. F., van Noije, T. P. C., Van Roozendael, M., De Smedt, I., Peters, D. H. M. U., and Meijer, E. W.: Trends, seasonal variability and dominant $\mathrm{NO}_{\mathrm{x}}$ source derived from a ten year record of $\mathrm{NO}_{2}$ measured from space, $\mathrm{J}$. Geophys. Res., 113, D04302, doi:10.1029/2007JD009021, 2008. van der Werf, G. R., Randerson, J. T., Giglio, L., Collatz, G. J., Kasibhatla, P. S., and Arellano Jr., A. F.: Interannual variability in global biomass burning emissions from 1997 to 2004, Atmos. Chem. Phys., 6, 3423-3441, doi:10.5194/acp-6-3423-2006, 2006.

van Donkelaar, A., Martin, R. V., Leaitch, W. R., Macdonald, A. M., Walker, T. W., Streets, D. G., Zhang, Q., Dunlea, E. J., Jimenez, J. L., Dibb, J. E., Huey, L. G., Weber, R., and Andreae, M. O.: Analysis of aircraft and satellite measurements from the Intercontinental Chemical Transport Experiment (INTEX-B) to quantify long-range transport of East Asian sulfur to Canada, Atmos. Chem. Phys., 8, 2999-3014, doi:10.5194/acp-8-2999-2008, 2008.

Wang, S. W., Streets, D. G., Zhang, Q., He, K. B., Chen, D., Kang, S. C., Lu, Z. F., and Wang, Y. X.: Satellite detection and model verification of $\mathrm{NO}_{\mathrm{X}}$ emissions from power plants in Northern China, Environ. Res. Lett., 5, 044007, doi:10.1088/17489326/5/4/044007, 2010.

Wang, Y., Jacob, D. J., and Logan, J. A.: Global simulation of tropospheric $\mathrm{O}_{3}-\mathrm{NO}_{\mathrm{x}}$-hydrocarbon chemistry, 1 . Model formulation, J. Geophys. Res., 103(D9), 10713-10726, 1998.

Wang, Y. X., McElroy, M. B., Martin, R. V., Streets, D. G., Zhang, Q., and Fu, T.-M.: Seasonal variability of $\mathrm{NO}_{\mathrm{x}}$ emissions over east China constrained by satellite observations: Implications for combustion and microbial sources, J. Geophys. Res., 112, D06301, doi:10.1029/2006JD007538, 2007.

Weil, J. C., Sullivan, P. P., and Moeng, C.-H.: The use of large-eddy simulations in Lagrangian particle dispersion models, J. Atmos. Sci., 61, 2877-2887, 2004.

Wenig, M., Spichtinger, N., Stohl, A., Held, G., Beirle, S., Wagner, T., Jähne, B., and Platt, U: Intercontinental transport of nitrogen oxide pollution plumes, Atmos. Chem. Phys., 3, 387-393, doi:10.5194/acp-3-387-2003, 2003.

Yevich, R. and Logan, J. A.: An assessment of biofuel use and burning of agricultural waste in the developing world, Global Biogeochem. Cy., 17, 1095, doi:10.1029/2002GB001952, 2003.

Yienger, J. J. and Levy, U. H.: Empirical model of global soilbiogenic $\mathrm{NO}_{\mathrm{x}}$ emissions, J. Geophys. Res., 100, 11447-11464, 1995.

Zhang, Q., Streets, D. G., He, K. B., Wang, Y. X., Richter, A., Burrows, J. P., Uno, I., Jang, C. J., Chen, D., Yao, Z. L., and Lei, Y.: $\mathrm{NO}_{\mathrm{x}}$ emission trends for China, 1995-2004: The view from the ground and the view from space, J. Geophys. Res., 112, D22306, doi:10.1029/2007JD008684, 2007.

Zhang, Q., Streets, D. G., Carmichael, G. R., He, K. B., Huo, H., Kannari, A., Klimont, Z., Park, I. S., Reddy, S., Fu, J. S., Chen, D., Duan, L., Lei, Y., Wang, L. T., and Yao, Z. L.: Asian emissions in 2006 for the NASA INTEX-B mission, Atmos. Chem. Phys., 9, 5131-5153, doi:10.5194/acp-9-5131-2009, 2009a.

Zhang, Q., Streets, D. G., and He, K. B.: Satellite observations of recent power plant construction in Inner Mongolia, China, Geophys. Res. Lett., 36, L15809, doi:10.1029/2009GL038984, 2009b.

Zhao, C. and Wang, Y. H.: Assimilated inversion of $\mathrm{NO}_{\mathrm{x}}$ emissions over east Asia using $\mathrm{OMI} \mathrm{NO}_{2}$ column measurements, Geophys. Res. Lett., 36, L06805, doi:10.1029/2008GL037123, 2009. 
Zhao, Y., Wang, S. X., Duan, L., Lei, Y., Cao, P. F., and Hao, J. M.: Primary air pollutant emissions of coal-fired power plants in China: Current status and future prediction, Atmos. Environ., 42, 8442-8452, 2008.
Zhao, Y., Nielsen, C. P., Lei, Y., McElroy, M. B., and Hao, J: Quantifying the uncertainties of a bottom-up emission inventory of anthropogenic atmospheric pollutants in China, Atmos. Chem. Phys., 11, 2295-2308, doi:10.5194/acp-11-2295-2011, 2011. 